\title{
A Compilation of the Stable Isotopic Compositions of Carbon, Nitrogen, and Sulfur in Soft Body Parts of Animals Collected from Deep-Sea Hydrothermal Vent and Methane Seep Fields: Variations in Energy Source and Importance of Subsurface Microbial Processes in the Sediment-Hosted Systems
}

\author{
Toshiro Yamanaka, Sho Shimamura, Hiromi Nagashio, Shosei Yamagami, \\ Yuji Onishi, Ayumi Hyodo, Mami Mampuku, and Chitoshi Mizota
}

\begin{abstract}
The stable isotopic signatures of biophilic elements, such as carbon, nitrogen, and sulfur, exhibited in animal soft body parts are excellent indicators for evaluating the pathways of energy and food sources. Thioautotrophic and methanotrophic nutrition prevailed in deep-sea hydrothermal vent and methane seep areas results in sulfide-sulfur and methanecarbon isotopic ratios. In this study, we reevaluated the carbon, nitrogen, and sulfur isotope compositions of animals taken from deep-sea hydrothermal vents and methane seep areas in order to understand the detailed pathways of energy and food sources for the habitants. The results showed that most animals collected from sediment-starved hydrothermal areas rely on thioautotrophic nutrition, using hydrogen sulfide dissolved in venting fluids as the sole primary energy source. On the other hand, animals from sediment-covered hydrothermal vent and cold seep fields show some variations in energy sources, of both hydrothermal and microbial origins. Sediment-covered areas tend to be enriched in biomass and diversity relative to sediment-starved areas. The results suggest that fluid discharged through sediments to the seafloor are strongly affected by subsurface microbial processes and result in increased biomass and diversity of the seafloor animal community.
\end{abstract}

The online version of this chapter (doi:10.1007/978-4-431-54865-2_10)

contains supplementary material, which is available to authorized users.

T. Yamanaka $(\bowtie) \bullet$ S. Shimamura $\bullet$ H. Nagashio

S. Yamagami $\bullet$ Y. Onishi

Graduate School of Natural Science and Technology, Okayama

University, 1-1, Naka 3-chome, Kita-ku, Okayama 700-8530, Japan

e-mail: toshiroy@cc.okayama-u.ac.jp

\section{A. Hyodo}

Faculty of Science, Kyushu University, 6-10-1, Hakozaki,

Higashi-ku, Fukuoka 812-8581, Japan

M. Mampuku

Graduate School of Social and Cultural Studies, Kyushu University,

4-2-1, Ropponmatsu, Chuo-ku, Fukuoka 810-8560, Japan

C. Mizota

Faculty of Agriculture, Iwate University, 3-18-8 Ueda, Morioka,

Iwate 020-8550, Japan 
Keywords

Chemosynthesis-based animals • Food ecology • Hydrothermal vent community • Methane seep community $\bullet$ Stable isotopes

\subsection{Introduction}

Since the first discovery of hydrothermal vent communities in 1977, the stable isotopic signatures of chemosynthesisbased animal species have been used to evaluate the isolation of vent communities from the usual marine food web systems that are supported by photoautotrophic primary production (e.g., Nelson and Fisher 1995; Mizota and Yamanaka 2003). Average carbon isotopic composition of marine photoautotrophic products produced by phytoplankton have been documented at $\delta^{13} \mathrm{C}=\sim-22 \%$, although they show a wide range $\left(\delta^{13} \mathrm{C}=-16\right.$ to $-28 \%$ o), reflecting a variety of carbon fixation pathways together with physicochemical conditions (e.g., Rees et al. 1978). The sulfur isotopic compositions of common marine animals, supported by the same photoautotrophic production, reflect the signature of sulfates dissolved in seawater, which is uniform throughout the oceans $\left(\delta^{34} \mathrm{~S}=+21 \%\right.$ ) (Rees et al. 1978) and the sole nutrient source of sulfur for primary producers. On the other hand, it is reported that the carbon isotopic ratios of thioautotrophic microbes that use the Calvin cycle involving RuBisCO (ribulose 1,5-bisphosphate carboxylase/oxygenase) for carbon fixation have a relatively narrow range of $\delta^{13} \mathrm{C}$ values, namely $-35 \pm 5 \%$, and it is known that other types of thioautotrophic microbes have significantly higher $\delta^{13} \mathrm{C}$ values $(\geq-20 \%$ ) (e.g., Nelson and Fisher 1995; Markert et al. 2007). Furthermore, sulfur isotopic ratios of thioautotrophic microbes reflect sulfide nutrition with a limited kinetic isotope effect ( -5\%o) through the cell membrane (Fry et al. 1983). In natural environments, $\delta^{34} \mathrm{~S}$ values of sulfides, which are mainly derived from volcanism and bacterial sulfate reduction, are clearly lower than those of sulfate-sulfur dissolved in seawater (e.g., Thode 1988; Canfield 2001). In the case of methanotrophic microbes, which are another important primary producer in the seep food web, carbon isotopic ratios reflect methane nutrition, while sulfur isotopic ratios reflect seawater sulfate-sulfur, similar to photoautotrophs. Some of the methane derived from pyrolysis of organic matter have carbon isotopic ratios similar to those of photoautotrophic products. Nevertheless, microbial methane, which prevails in anoxic sediments, has significantly lower $\delta^{13} \mathrm{C}$ values ( $\leq-45 \%$ ), whereas abiotic methane has distinguishably high $\delta^{13} \mathrm{C}$ values (>-20\%) (e.g., Schoell 1988).

However, the nitrogen sources for chemosynthesis-based animals are not well understood (Kennicutt et al. 1992; Fisher et al. 1994). Previously reported $\delta^{15} \mathrm{~N}$ values for soft tissues from thiotrophic and methanotrophic animals range from -20 to +7 \%o (e.g., Nelson and Fisher 1995; Mizota and Yamanaka 2003). Such negative $\delta^{15} \mathrm{~N}$ values of marine animal soft tissues have been reported only in communities consisting of chemosynthesis-based animals (e.g., Saino and Ohta 1989; Fiala-Médioni et al. 1993; Mizota and Yamanaka 2003) and cyanobacteria, which have the ability to fix dinitrogen ( -3 to $+0 \%$ ) (Minagawa and Wada 1984; Carpenter et al. 1997). The nitrogen nutrition of symbiotic bacteria is not well understood.

Stable isotopic signatures are quite useful indicators for distinguishing chemosynthesis-based animals from the phototrophic food web. Their isotopic signatures can possibly be used to identify the energy source for chemosynthesis. Mizota and Yamanaka (2003) reviewed the carbon, nitrogen, and sulfur isotopic compositions of chemosynthesis-based animals and the associated methane and sulfide data published prior to 2003, and discussed the flow of chemical energy from emitting fluids to the animal community. In the review, the importance of environmental isotopic data sets of sulfide-, methane-, and nitrogen-issuing species, was emphasized. Nevertheless, environmental isotopic data sets have not been fully integrated. Some animal clusters have been found far from vents where significant concentrations of sulfide and methane have been detected. Furthermore, $\delta^{15} \mathrm{~N}$ values of nitrate, nitrite, and ammonium from the environment have not been reported. Most reported geochemical data from hydrothermal and seep fields are derived from venting fluids and visible seepages. This implies that the reported values are almost comparable to the end-member (i.e., deep-seated source) values. Therefore, it is difficult to directly compare the isotopic data to the soft body parts of animals, especially in sediment-hosted systems (i.e., methane seeps and sediment-covered hydrothermal fields), where emitting fluids penetrate through thick clastic sediments and are subsequently subjected to subsurface microbial transformation. An obvious example is methane seep communities dominated by thiotrophic animals, which use microbial hydrogen sulfide derived from sulfate reduction with methane as an electron donor (e.g., Mizota and Yamanaka 2003).

In addition, reduced chemical species, such as hydrogen sulfide and methane discharged from the seafloor, are incorporated by chemosynthetic and methanotrophic microbes, and the resulting microbial products have been considered to support not only vent- and seep-endemic animal communities but also common benthic and epibenthic animals. In the case of hydrothermal systems, discharge of these chemicals mainly originates from venting chimneys. In fact, at hydrothermal fields lacking sediment cover, 

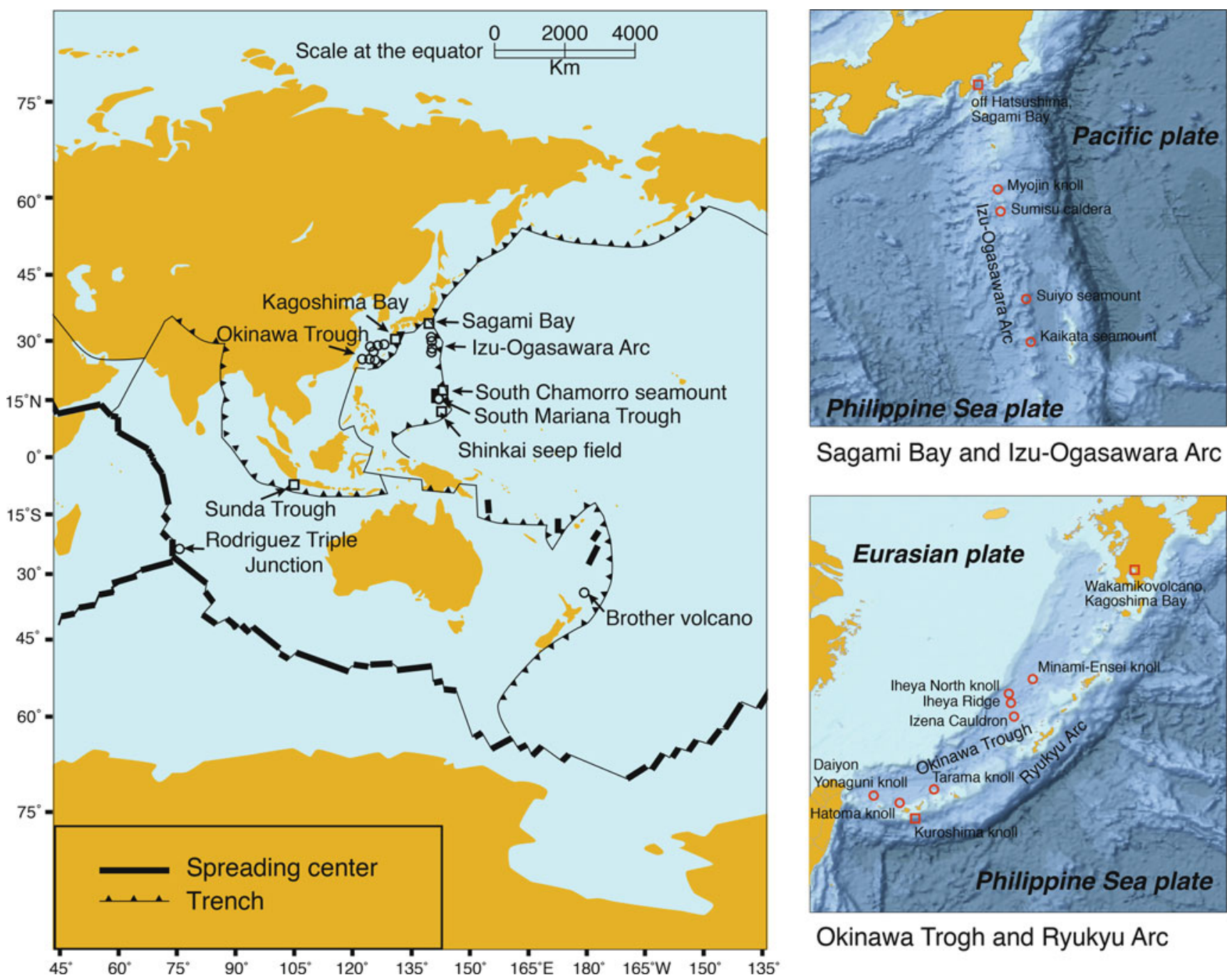

Sagami Bay and Izu-Ogasawara Arc

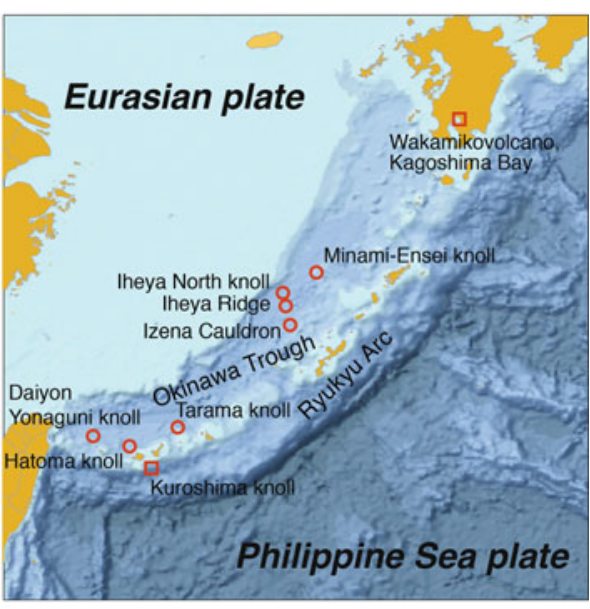

Okinawa Trogh and Ryukyu Arc

Fig. 10.1 Maps showing the sample locations of this study. Open circles indicate hydrothermal fields. Open squares indicate methane seep fields. The Wakamiko site in Kagoshima Bay and the Shinkai seep field of Southern Mariana are categorized as methane seeps

hydrothermal discharge is mostly confined to venting chimneys and underlying hydrothermal mounds. Hydrothermal fields covered by thick clastic sediments have a few additional pathways for hydrothermal fluid discharge, e.g., diffusion into aquifers in overlying sediments. The fluids diffused within the sediments provide reduced chemical species and other nutrients to subsurface microbes. Some of the microbes may be grazed upon, thereby supporting benthic animals, and the others may generate reduced chemical species once more. Such secondary chemicals are also thought to support chemosynthesis-based animals that inhabit hydrothermal field and methane seep communities mentioned above.

Since 2003, reconnaissance surveying and sampling of chemosynthesis-based animals using submersibles from Japan and other countries is ongoing, and the following isotopic analyses have been made. In this Chapter, we have compiled the latest isotopic data from soft tissues of diverse animals and environments located near hydrothermal vents and methane seeps of the extensive areas indicated in Fig. 10.1. We discuss the variations in energy and food sources of the environments from the view point of "TAIGA" (subseafloor fluid flow system, Urabe, Chap. 1), together with the importance of sub-seafloor microbial processes.

\subsection{Materials and Methods}

\subsubsection{Geological Background of the Sample Materials}

\subsubsection{Okinawa Trough}

The Okinawa Trough (Fig. 10.1) is a typical back-arc rifting basin between the east margin of the East China Sea and the Ryukyu Islands (e.g., Letouzey and Kimura 1986). The trough is filled with thick clastic sediments derived from surrounding 
continents and islands, together with volcaniclastic sediments associated with arc and back-arc volcanism in this area (Tsugaru et al. 1991; Ishibashi et al. Chap. 29). Vigorous hydrothermal activities associated with volcanism have been observed in the trough, and the chemistry of emitting fluids has been characterized by high volatiles (i.e., $\mathrm{CO}_{2}$ and methane) and ammonium concentrations, suggesting the significant interaction of magma with sedimentary organic matter (e.g., Ishibashi and Urabe 1995; Kawagucci, Chap. 35). Therefore, many of the hydrothermal activities in the Okinawa Trough are interpreted as a typical sedimenthosted system. Chemosynthesis-based animal communities have been found around the hydrothermal venting area, and they have been characterized by the presence of dense Bathymodiolus mussels, vestimentiferan tubeworms, and galatheid crab communities (e.g., Fujikura et al. 2012; Watanabe and Kojima, Chap. 40).

Animal samples were obtained from the following hydrothermal fields: Minami-Ensei knoll, Izena Hole, Iheya Ridge, Iheya North knoll, Tarama knoll, DaiyonYonaguni knoll, and Hatoma knoll (Fig. 10.1).

\subsubsection{Izu-Ogasawara Arc}

The Izu-Ogasawara Islands (Fig. 10.1) are a volcanic arc associated with subduction of the Pacific Plate beneath the Philippine Plate. Deep-sea hydrothermal activities have been identified in the calderas and craters of the submerged volcanoes (e.g., Glasby et al. 2000). The hydrothermal areas lack clastic sediments except for a small amount of volcaniclastic sediment that fills in the craters and calderas (e.g., Iizasa 1993; Takano et al. 2004). Relative to the fluids emitting from the Okinawa Trough, the resulting chemistry of the hydrothermal fluids is characterized by significantly lower methane and ammonium concentrations, i.e., a sediment-starved system (e.g., Ishibashi and Toki 2012). Chemosynthesis-based animal communities have been found around the fluid venting areas and have been characterized by occurrence of dense Bathymodiolus mussels (e.g., Fujikura et al. 2012).

Animal samples were collected from the following hydrothermal fields: Myojin Knoll, Sumisu caldera, Suiyo seamount, and Kaikata seamount (Fig. 10.1).

\subsubsection{Additional Hydrothermal Fields}

Animal samples were also collected from the following hydrothermal fields and used for isotopic analyses: three sites at the southern most portion of the Mariana back-arc spreading center in the South Mariana Trough (the Snail, Archaean, and Yamanaka sites), Brothers Volcano in the Kermadec Arc (New Zealand), and Hakuho Knoll at the Rodriguez Triple Junction (Central Indian Ridge) (Fig. 10.1). The lack of clastic sediments in the hydrothermal fields reflects ammonium concentrations $<20 \mu \mathrm{M} / \mathrm{kg}$ (Kato et al. 2009; de Ronde et al. 2011; Gamo et al. 2001), due to minimal contribution of sedimentary organic matter to the hydrothermal fluids. Bio-diversity of the animal communities observed at the Snail and Yamanaka sites in the South Mariana Trough was very low (Kojima and Watanabe, Chap. 26). Dense Alviniconcha snails (Wheat et al. 2003), crabs (Gandalfus sp.) and sea anemones (Marianactis sp.) have been identified. High bio-diversity, including dense long-necked barnacles (Volcanolepas osheai), shrimp (Alvinocaris sp.), and vestimentiferan tubeworms (Lamellibrachia sp.), has been observed in the animal community at the Brother Volcano site (Kermadec Arc), while many types of animals, such as Rimicaris shrimp, Bathimodiolus mussels, Alviniconcha snails (de Ronde et al. 2011), and Brachyuran crabs, have been observed at the Kairei hydothermal field on Hakuho Knoll (Central Indian Ridge) (Hashimoto et al. 2001; Watanabe and Beedessee, Chap. 16).

\subsubsection{Sagami and Kagoshima Bays and Kuroshima Knoll}

Sagami and Kagoshima Bays and Kuroshima Knoll (Fig. 10.1) are areas with significantly high methane flux from the seafloor (Masuzawa et al. 1992; Yamanaka et al. 2013). Sagami Bay and Kuroshima Knoll are located on the fore-arc regions, which are related to subduction of the Philippine Plate, where compression stress associated with subduction is a possible driving force for methane seepage. In Kagoshima Bay, methane rich gas is emitted from fumaroles, together with volcanic gas associated with the volcanic activity of the Wakamiko volcano. Sedimentary organic matter has been considered a primary source for methane as a result of microbial metabolism or pyrolysis. Chemosynthesis-based animal communities have been found around the seepages and have been characterized by the occurrence of dense Bathymodiolus mussel, Calyptogena clam, and vestimentiferan tubeworm communities (e.g., Fujikura et al. 2012).

\subsubsection{Additional Methane Seep Fields}

Methane seepages from the seafloor have been reported from South Chamorro Seamount (Northern Mariana Fore-arc) (Yamanaka et al. 2003b), Shinkai Seep Field (Southern Mariana Fore-arc) (Ohara et al. 2012), and the western edge of Sunda Trough (off southwest Java) (Okutani and Soh 2005) (Fig. 10.1), and characteristic animal communities have also been reported around the seepages. Calyptogena clams have been observed at all of these sites, while Bathymodiolus mussels are primarily observed on the South Chamorro Seamount. The South Chamorro Seamount is a large serpentine mud volcano, while the Shinkai Seep Field is an outcrop of serpentinized peridotite (Ohara et al. 2012). This suggests that methane emitting from these sites 
may be an abiotic product of the reaction between carbon dioxide and dihydrogen, which are expected to occur during serpentinization (Berndt et al. 1996). Serpentinization of the seafloor may be the cause of hydrothermal activity at sites such as the Rainbow and Lost City hydrothermal fields (Kelley et al. 2005). A detailed geochemical study has recently been conducted on the Shinkai Seep Field (Ohara et al. 2012). Therefore, in this study we have categorized this system as a methane seep.

Methane seepage at the Sunda Trough is located in a forearc basin covered with thick clastic sediments, suggesting that the tectonic background is comparable with the cold seepages of Sagami Bay. This means that the primary source of methane is expected to be organic matter of sedimentary origin.

\subsubsection{Animal, Sediment, and Fluid Sampling Procedures}

The animal samples used in this study are listed in Table 10.1. In addition to common marine benthic animals, such as sponges, sea cucumbers, starfishes, and fishes, well known chemosynthesis-based animals, including three bivalves (Calyptogena, Bathymodiolus, Acharax), two shrimps (Alvinocaris, Limicaris), two tubeworms (Lamellibrachia, Alaysia), one gastropoda (Alviniconcha), one galatheid crab (Shinkaia), among others, were analyzed for the carbon, nitrogen, and sulfur isotopic ratios in their soft tissues.

The sampling areas of the animals used in this study are also indicated in Table 10.1. The deep-sea hydrothermal fields of Okinawa Trough, Izu-Ogasawara Arc, Mariana Trough in the North Pacific Ocean, Kermadec Arc in the South Pacific Ocean, and Rodriguez Triple Junction in the Indian Ocean, and the methane seeps (cold seeps) of Kagoshima and Sagami Bays, Ryukyu and Mariana fore-arcs in the Pacific Ocean, and Sunda Trough in the Indian Ocean, were subjected to sample collection using submersibles (ROVs/ HyperDolphin and Kaiko, DSV/Shinkai 6500 belonging to JAMSTEC and RV/Ropos belonging to Canadian Scientific Submersible Facility).

During the dive studies, animal samples were collected with a suction sampler or manipulator equipped with the submersible. Fluid and sediments used for geochemical characterization were collected using all-titanium ALVINtype fluid samplers (Von Damm et al. 1985), gas-tight WHATS fluid samplers (Tsunogai et al. 2003), multicylinder type ROCS fluid samplers (Yamanaka et al. 2013), and NISKIN bottles equipped with the submersibles. The fluid and sediment samples were collected as close as possible to the animal habitat in order to evaluate the relationship between the animal soft bodies and the energy sources for the chemosynthesis-based animal communities, using isotopic signatures.

\subsubsection{Analytical Procedures}

Soft tissues of bivalve and gastropoda samples were dissected into gill, foot, mantle, adductor and viscera sections, and subjected to isotopic analyses. For vestimentiferan tubeworm samples, the soft body parts were dissected into gill, vestimentifera, and trophosome sections, and the trophosome sections were used for the analyses. Muscle samples were separated from the crustacean species. Other animals, such as limpets, sponges, polychaetes, etc., were used as whole-body samples due to small size or complex anatomy. The tissues dissected for analyses were treated with $1 \mathrm{M}$ hydrochloric acid to remove carbonates, then freeze-dried prior to grinding. Preparation for sulfur isotopic measurements in the soft tissues was described previously (Mizota et al. 1999; Yamanaka et al. 2000a, b). Briefly, to remove excess seawater sulfate, the dissected soft tissues were dialyzed repeatedly in cellulose bags against $1 \mathrm{M}$ lithium chloride solution at $5{ }^{\circ} \mathrm{C}$. Dialyzed samples were then freeze-dried and pulverized. Samples of large size ( $\geq 1 \mathrm{~g}$ dry weight) were placed in a Parr bomb 1108 Oxygen Combustion Vessel (a stainless steel vessel filled with oxygen gas under high-pressure $\left(30 \mathrm{~kg} / \mathrm{cm}^{2}\right)$ and a few milliliters of distilled water). After combustion, the dried samples were completely converted into gas, and all sulfur compounds were trapped as sulfates in the distilled water within the vessel. The resulting sulfates were precipitated as $\mathrm{BaSO}_{4}$. The dried soft tissue samples were measured for carbon, nitrogen, and sulfur isotopic ratios using an EA/irMS (IsoPrime coupled with Euro Vector EA3000, GV Instruments, UK, and Delta Plus coupled with CE Instrument NA2500, Thermo Quest, USA). Small-sized samples for sulfur isotope analysis were wrapped within tin capsules and directly subjected to EA/irMS.

Sulfide-sulfur were recovered from the substrate sediments by treatment with warm $\left(\leq 80{ }^{\circ} \mathrm{C}\right) 30 \%$ hydrogen peroxide solution to generate sulfates, which were finally converted into $\mathrm{BaSO}_{4}$. Dissolved sulfide in the hydrothermal fluids was fixed on board in order to precipitate zinc sulfide, and then it was converted to sulfate for recovery as $\mathrm{BaSO}_{4}$ precipitate. The $\mathrm{BaSO}_{4}$ precipitate was converted into $\mathrm{SO}_{2}$ gas, as described by Yanagisawa and Sakai (Yanagisawa and Sakai 1983).

The concentration and carbon isotope composition of the dissolved methane in the water samples were determined following the methods of Tsunogai et al. (2000), using an isotope-ratio-monitoring-GC/MS (MAT 252, Thermo Quest, USA). The methane content in the samples was calculated by comparing the ${ }^{44} \mathrm{CO}_{2}$ output with that of a working standard gas containing c. 500 ppm methane in nitrogen.

All of the isotopic values were expressed using $\delta$ notation as a per mill deviation (\%o) from international reference materials (VPDB for $\delta^{13} \mathrm{C}$, CDT for $\delta^{34} \mathrm{~S}$ and atmospheric $\mathrm{N}_{2}$ for $\delta^{15} \mathrm{~N}$, respectively). Analytical errors associated with the overall process of these determinations were $0.2,0.3$, and $0.3 \%$, respectively. 


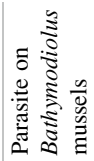

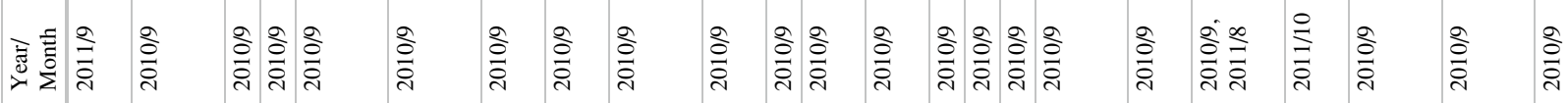

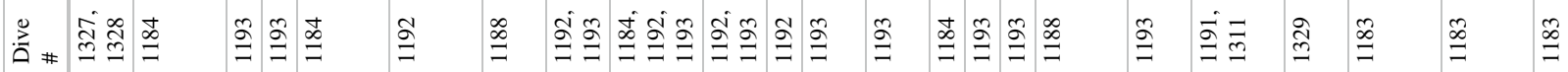

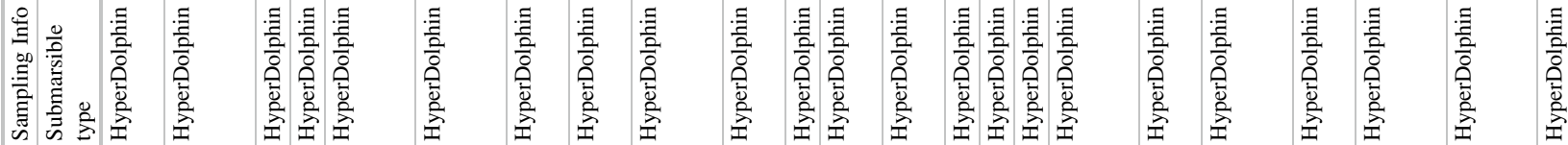

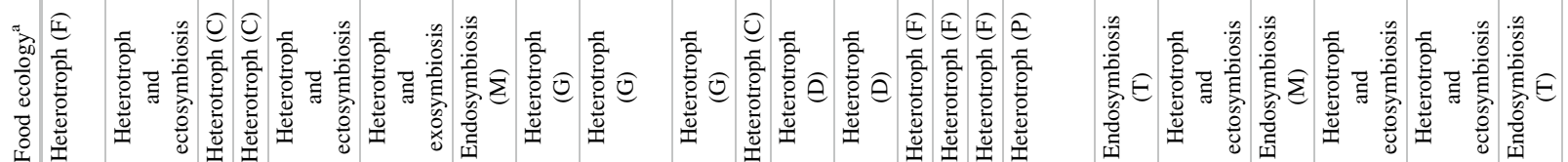

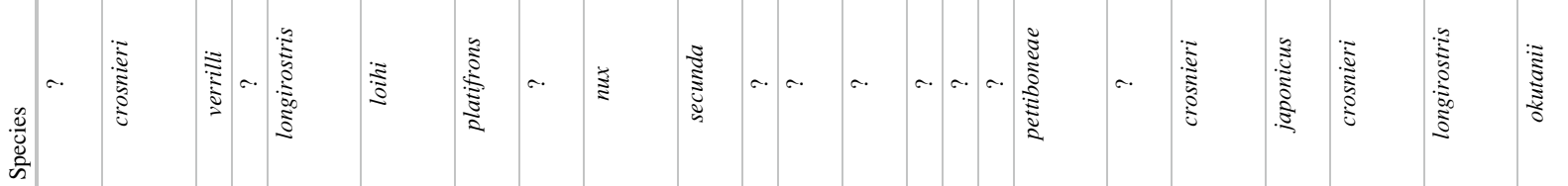

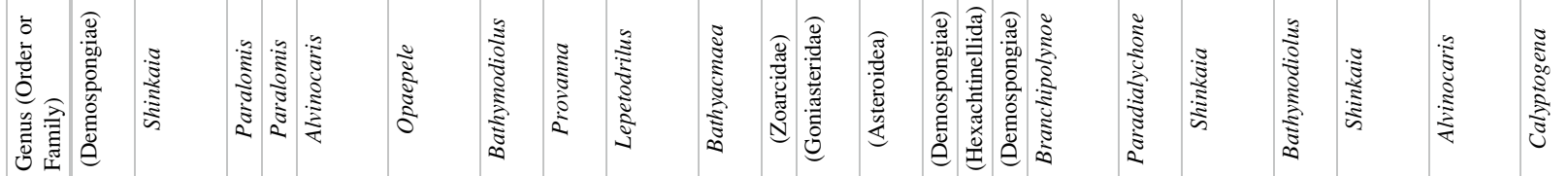

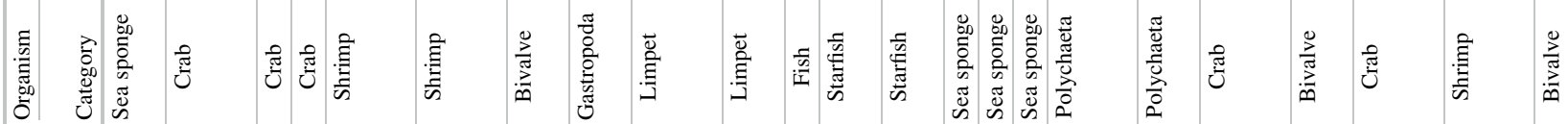

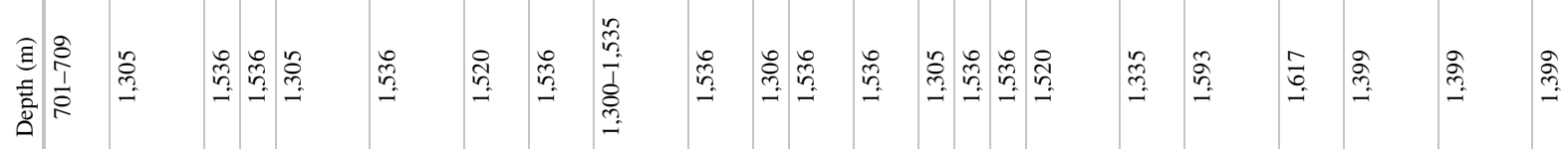

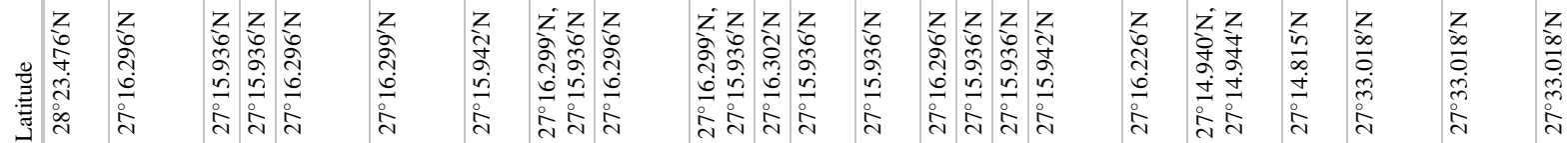

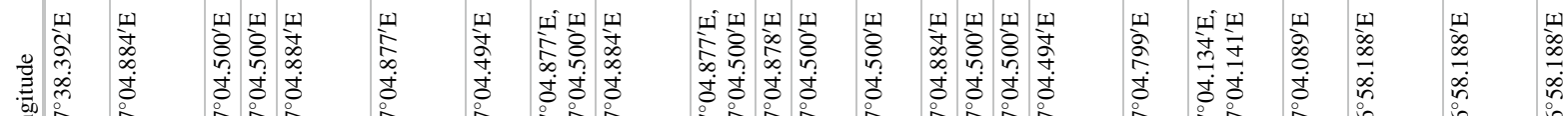

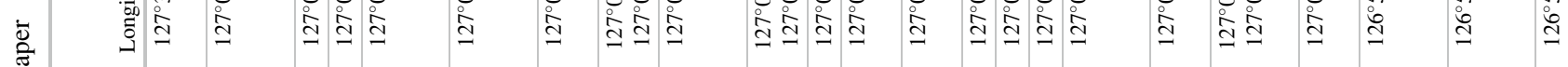

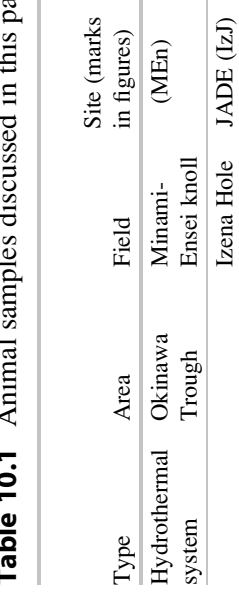




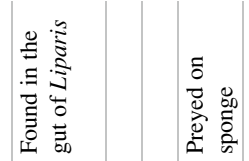

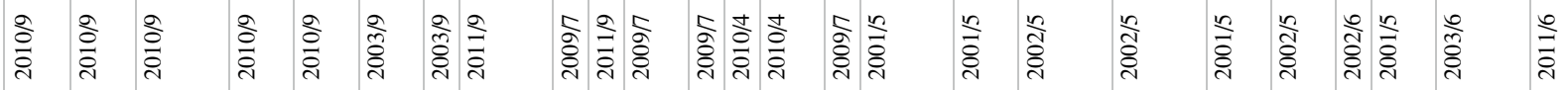

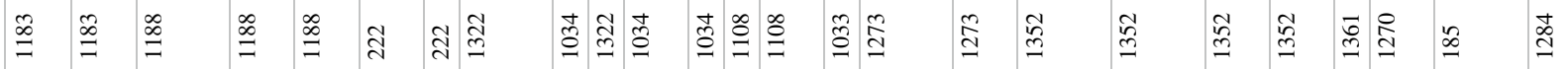

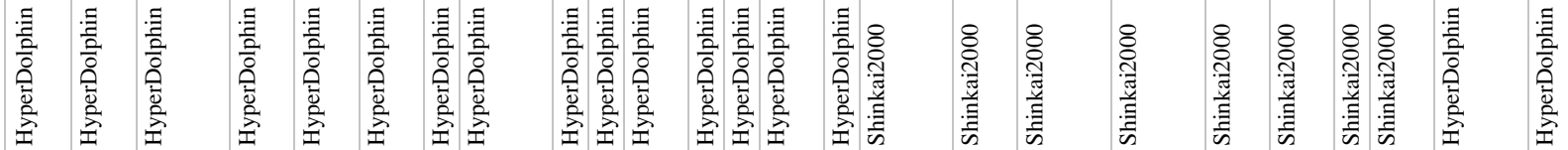

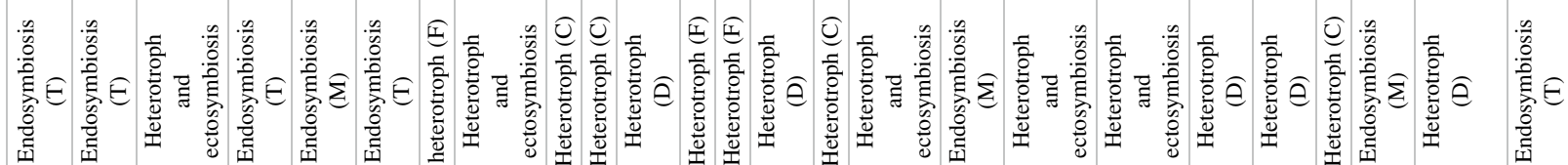

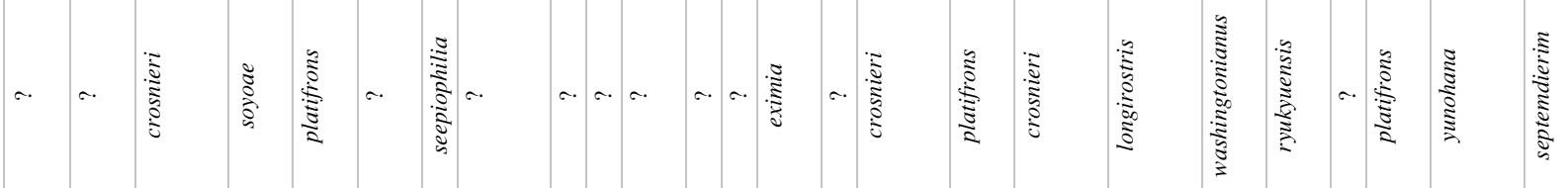

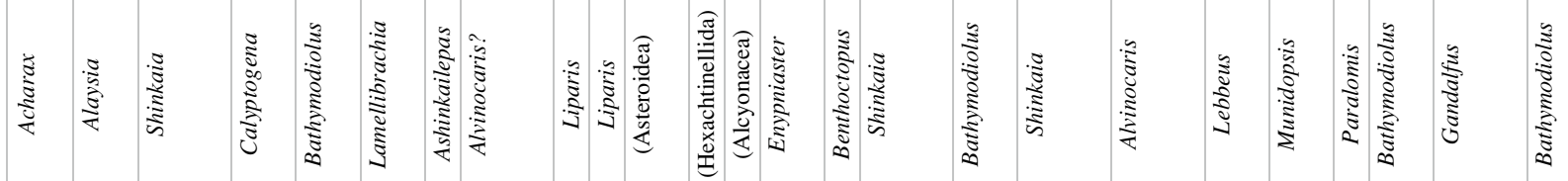

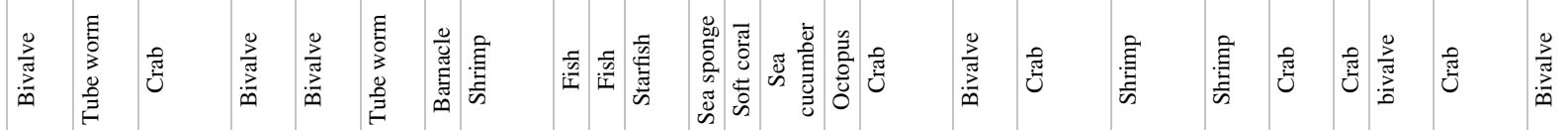

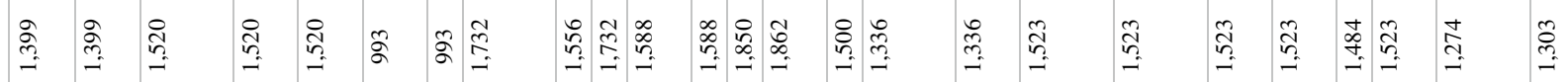

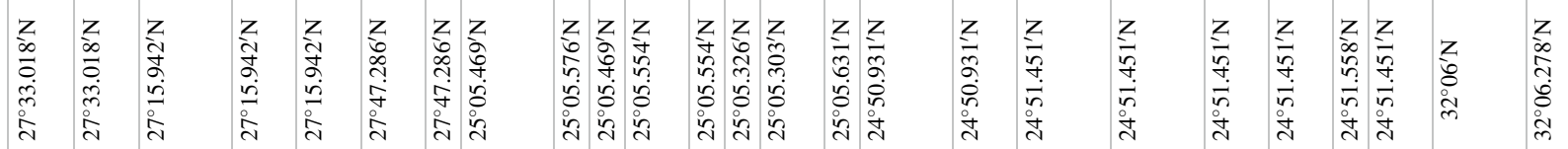

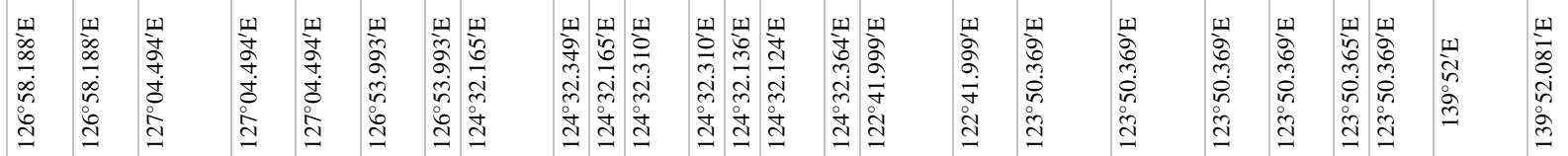

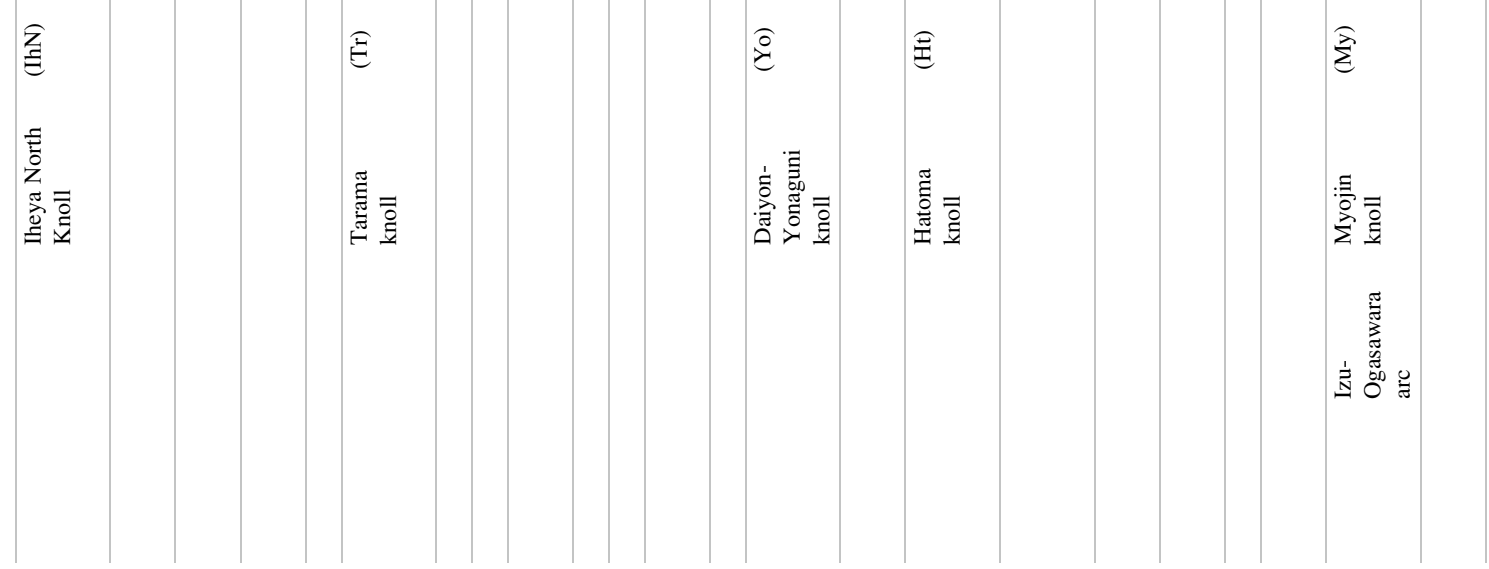




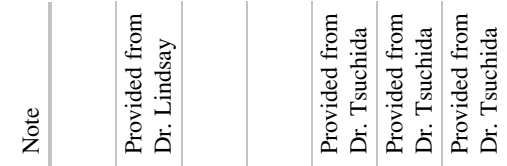

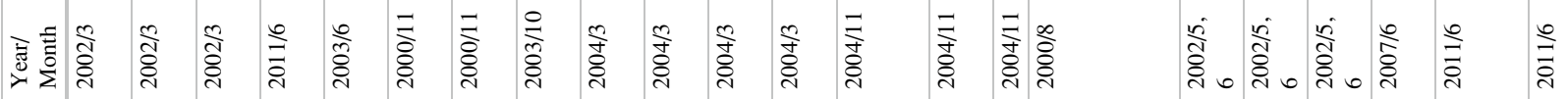

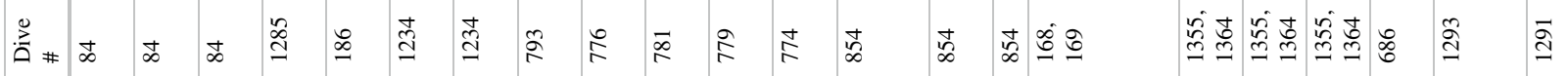

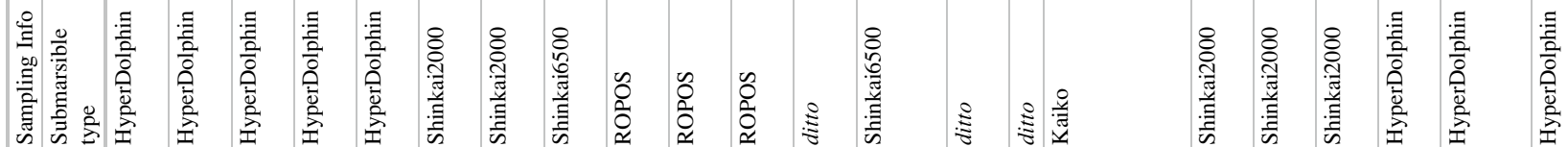

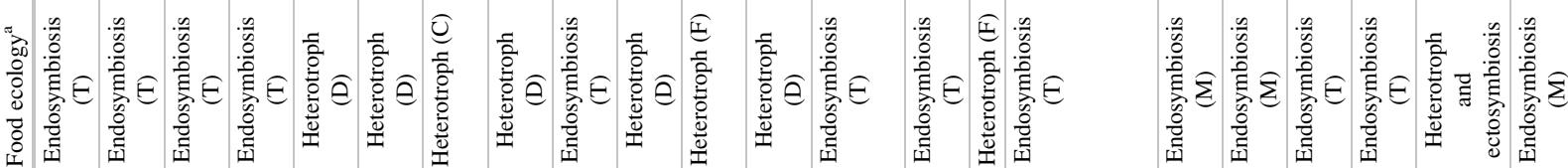

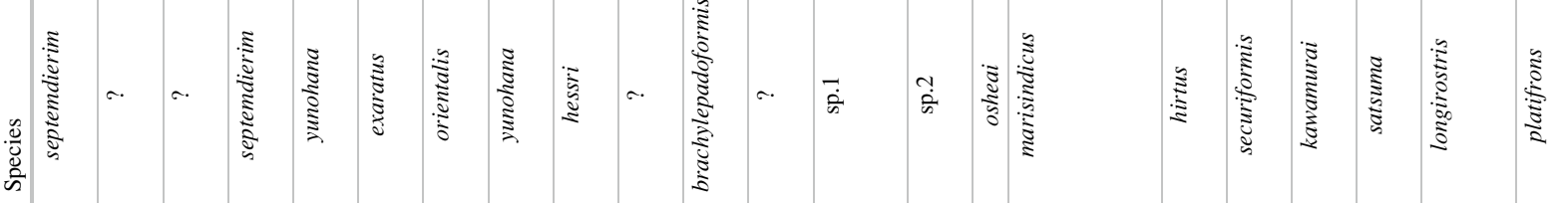

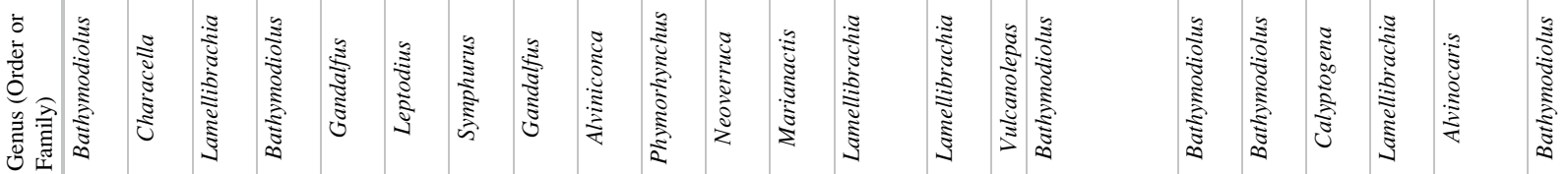

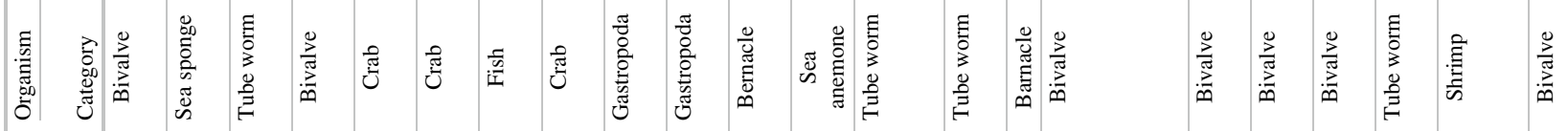

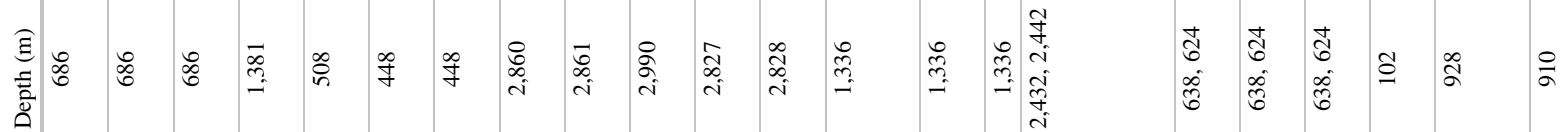

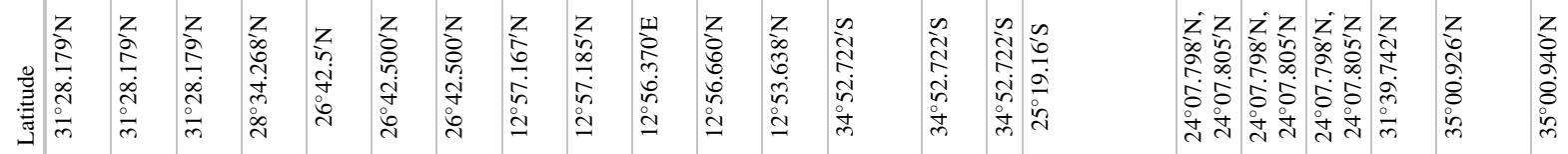

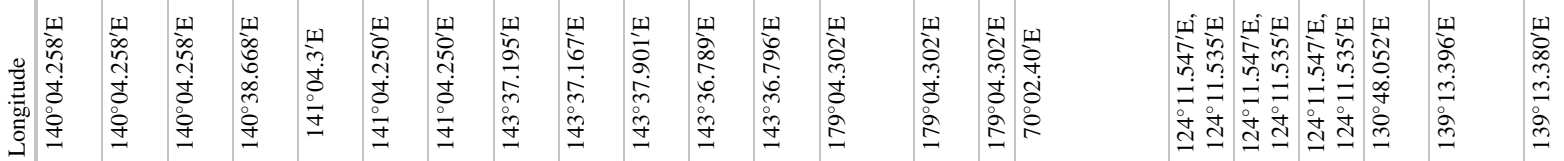

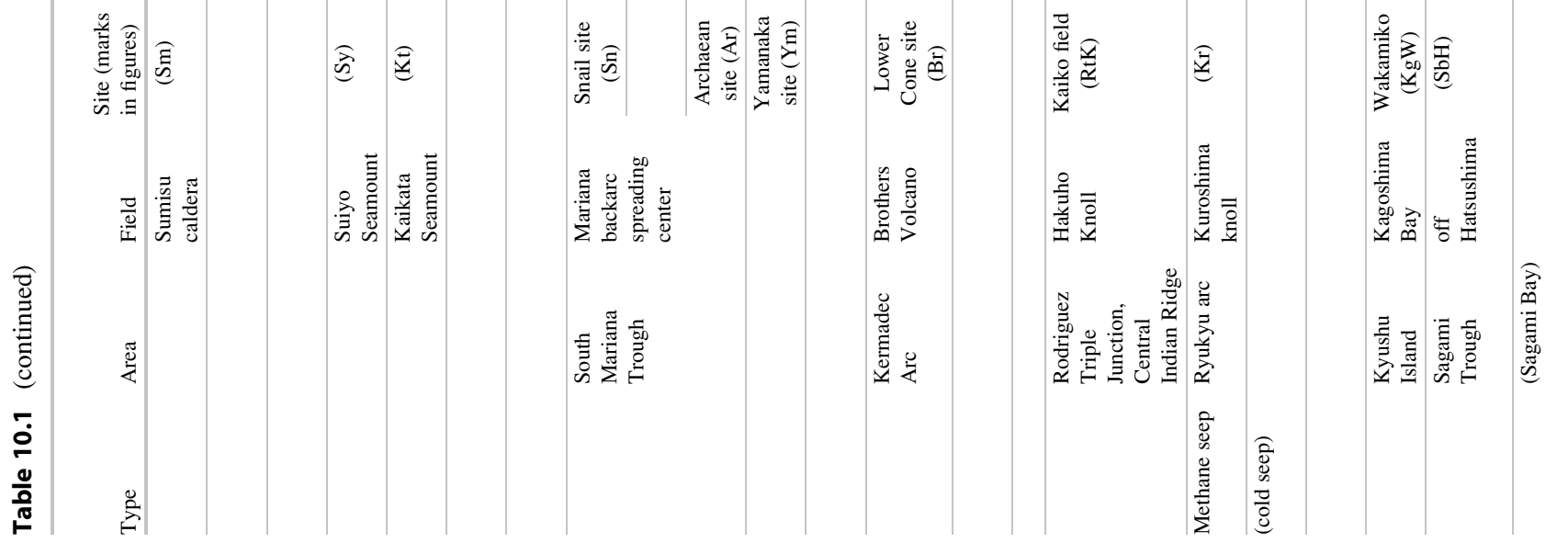




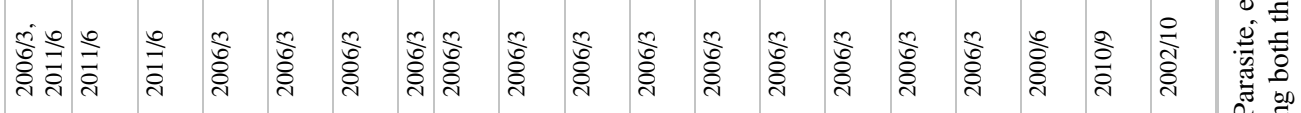

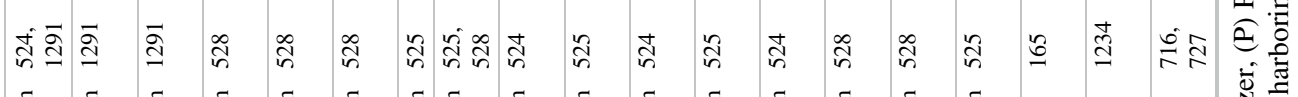

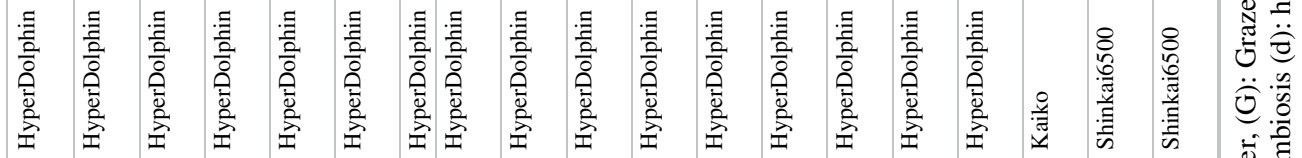

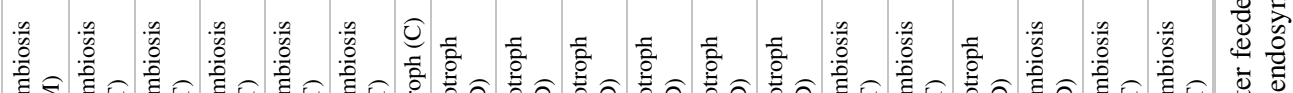

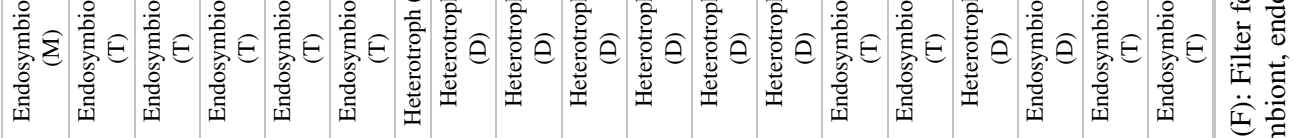

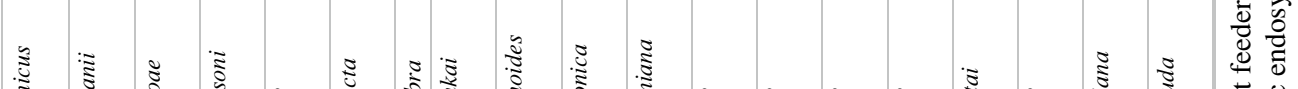

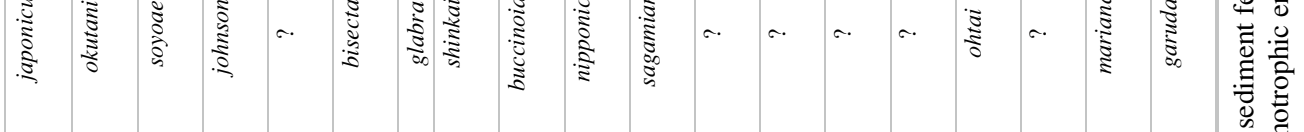
そ)

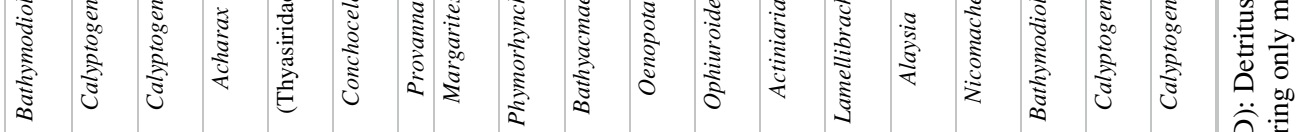

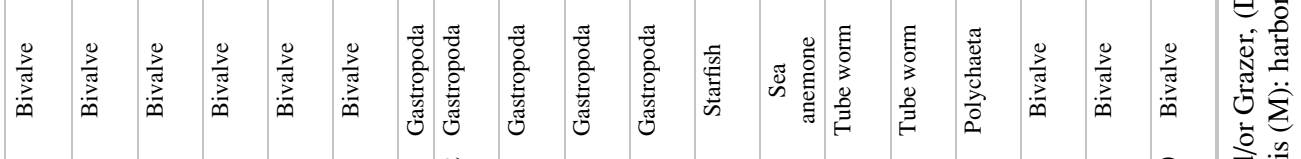

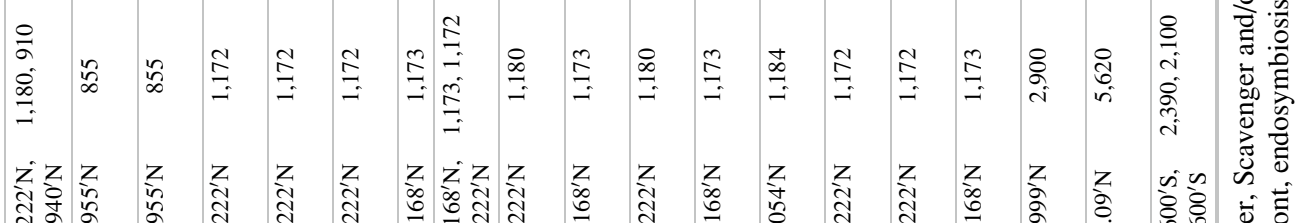

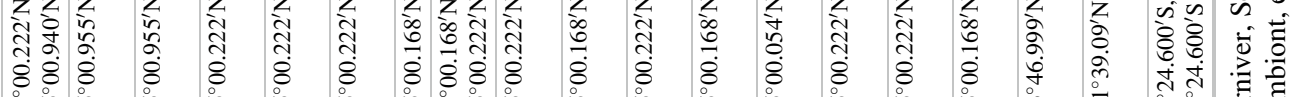

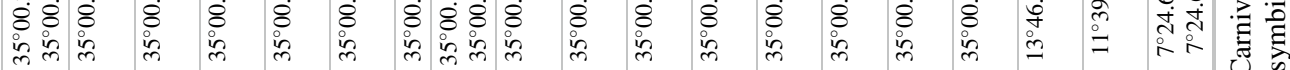

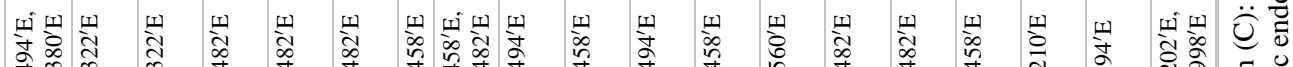

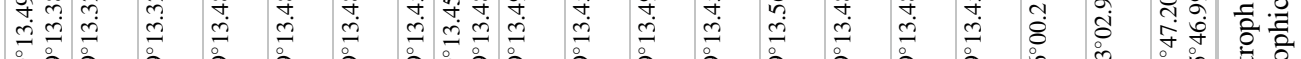

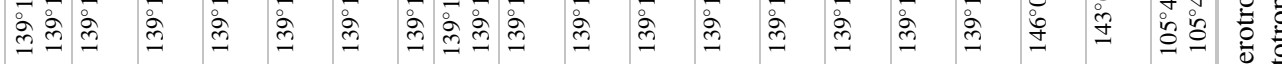

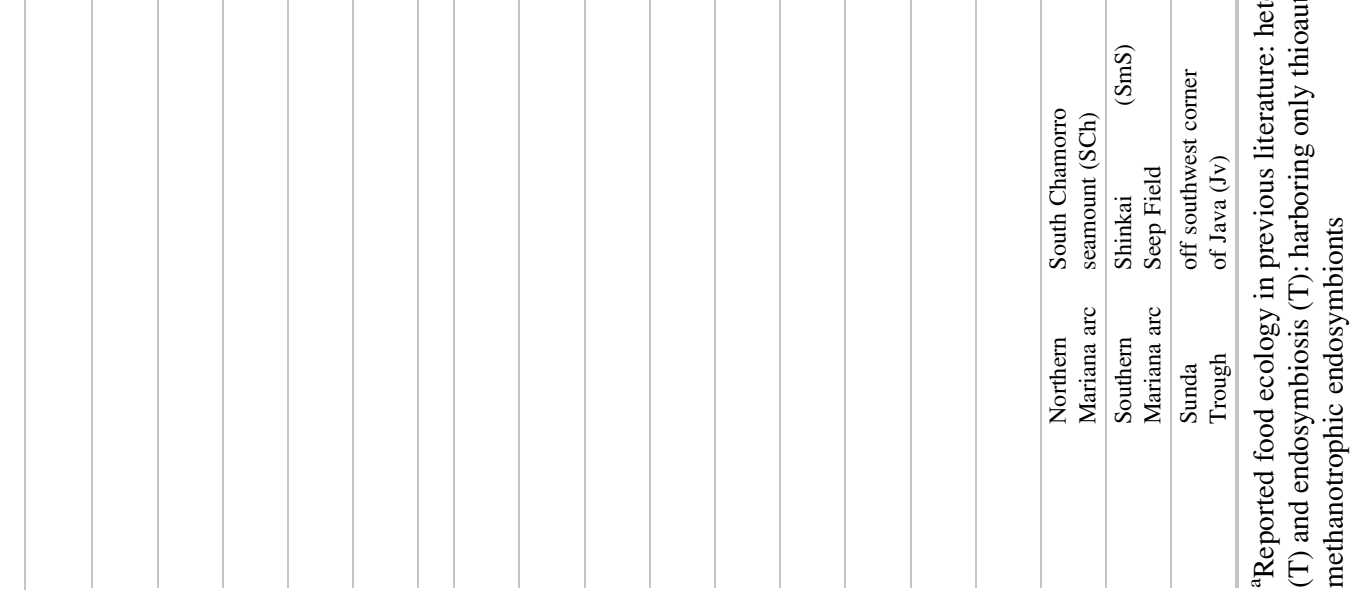




\subsection{Analytical Results for Isotopic Composition}

\subsubsection{Isotopic Compositions of Animal Samples from Hydrothermal Fields}

The analytical results for the isotopic compositions of animal soft body parts and issuing fluids are summarized in Tables 10.2 and 10.3. Diagrams of the relationships among nitrogen and sulfur isotopic ratios vs. carbon isotopic ratios are shown in Figs. 10.2 and 10.3. Abbreviations in the figures indicate the locations of the samples (red-colored abbreviations indicate sediment-starved hydrothermal fields, see Table 10.1), and the asterisks to the right of the abbreviations indicate the species that harbor methanotrophic endosymbionts. The diagrams also indicate the approximate ranges of common marine organisms that rely on phototrophic products (insert enclosed by green dotted box). The $\delta^{13} \mathrm{C}$ vs. $\delta^{15} \mathrm{~N}$ plot in Fig. 10.2 shows that many animals, especially crustacean species, were among the range of common marine organisms, while the $\delta^{13} \mathrm{C}$ vs. $\delta^{34} \mathrm{~S}$ plot (Fig. 10.3) indicates that most samples had lower $\delta^{34} S$ values $(<+15 \%)$, relative to the common marine organisms. Calyptogena clams, indicated by open circles, had a typical thioautotrophic range of $\delta^{13} \mathrm{C}=-35 \pm 5 \%$ and $\delta^{34} \mathrm{~S} \ll+15 \%$, while Bathymodiolus mussels, which harbor thioautotrophic and/or methanotrophic endosymbionts in their gill tissues, showed wider $\delta^{13} \mathrm{C}$ values ranging from -50 to $-25 \%$ and significantly low $\delta^{15} \mathrm{~N}$ values $(<0 \%$, Fig. 10.2). Nearly all methanotrophic mussels had high $\delta^{34} S$ values, close to $+15 \%$, while the thiotrophic mussels had significantly lower $\delta^{34} \mathrm{~S}$ values, relative to the other mussels. Vestimentiferan tubeworms, indicated by open cross symbols, also had a wide range of $\delta^{13} \mathrm{C}$ values ( -35 to $-12 \%$ ), indicating that they harbor thioautotrophic endosymbionts with various types of carbon fixation pathways in addition to the Calvin cycle. Certain animal samples (Alvinocaris shrimp, Alaysia tubeworms at Iheya Ridge field, Ashinkailepas barnacles at Iheya North knoll, Bathymodiolus mussels at Sumisu caldera, and Lamellibrachia tubeworms at Brother seamount) had significantly lower $\delta^{34} \mathrm{~S}$ values $(<-10 \%)$, relative to the hydrogen sulfide issuing from the associated hydrothermal vents.

\subsubsection{Isotopic Compositions of Animal Samples from Methane Seep Fields}

Analytical results for animal soft tissues and issuing fluids are summarized in Table 10.3. Figures 10.4 and 10.5 show relationships comparable to those shown for the hydrothermal fields. Samples without abbreviations represent collections off Hatsushima, in Sagami Bay. Nearly all data were beyond the range of common marine organisms. Calyptogena clams, as shown by open circles, were located in the typical thioautotrophic range, as were the specimens obtained from hydrothermal fields, with one exception: Calyptogena soyoae off Hatsushima $\left(\delta^{34} \mathrm{~S}=+16.8 \%\right.$ \%). Except for two groups of samples from Kuroshima knoll $\left(\delta^{34} \mathrm{~S}=+10.6,+7.2\right.$ for gill tissues $)$, methanotrophic Bathymodiolus mussels had high $\delta^{34} \mathrm{~S}$ values, which are comparable to those of common marine organisms. Some of the bivalves (Bathymodiolus, Calyptogena, and Acharax) showed significantly low $\delta^{15} \mathrm{~N}$ values $<-5 \%$. Bathymodiolus mussels also showed significantly low $\delta^{15} \mathrm{~N}$ values as well as the lowest $\delta^{13} \mathrm{C}$ values. It appeared that the $\delta^{13} \mathrm{C}$ and $\delta^{15} \mathrm{~N}$ values of these samples are positively correlated $\left(\mathrm{R}^{2}=0.85\right)$.

\subsubsection{Stable Isotopic Composition of the Issuing Fluids Associated with Animal Communities}

\subsubsection{Hydrogen Sulfide}

The $\delta^{34} \mathrm{~S}$ values of hydrogen sulfide dissolved in the hydrothermal fluids ranged from nearly 0 to $+12 \%$ (Table 10.2), whereas those from methane-rich seeps were less than $-20 \%$, except for the fumarolic gas emitting from Wakamiko submarine volcano (Table 10.3). Thiotrophic animals, which are known to harbor only thioautotrophic endsymbionts or feed on thioautotrophic products, are expected to have $\delta^{34} \mathrm{~S}$ values close to that of the associated hydrogen sulfide. Therefore, the apparent sulfur isotopic fractionation between the soft tissue of thiotrophic animals and the associated hydrogen sulfide collected from the hydrothermal systems should be zero or nearly zero. As shown in Fig. 10.6, most $\delta^{34} \mathrm{~S}$ values of the animals were lower than those of the hydrogen sulfides, while some animals showed values slightly higher than those of the hydrogen sulfides. On the other hand, methanotrophic species, which are known to harbor methanotrophic endsymbionts, and heterotrophs relying on phototrophic products are expected to have high $\delta^{34} \mathrm{~S}$ values, ranging from +15 to $+21 \%$, since they assimilate seawater sulfates with $\delta^{34} \mathrm{~S}$ values of $\sim+21 \%$. Figures 10.7 and 10.8 show the apparent differences between the $\delta^{34} \mathrm{~S}$ values of animal soft tissues and seawater-sulfate for samples from hydrothermal systems and methane seeps, respectively. The diagrams show that, with some exceptions, especially bivalves inhabiting methane seeps (Bathymodiolus japonicas, $B$. platifrons, B. hirtus, and B. securifornis in Fig. 10.8), $\delta^{34} \mathrm{~S}$ values for all animal tissues were significantly lower than that of seawater-sulfate. 


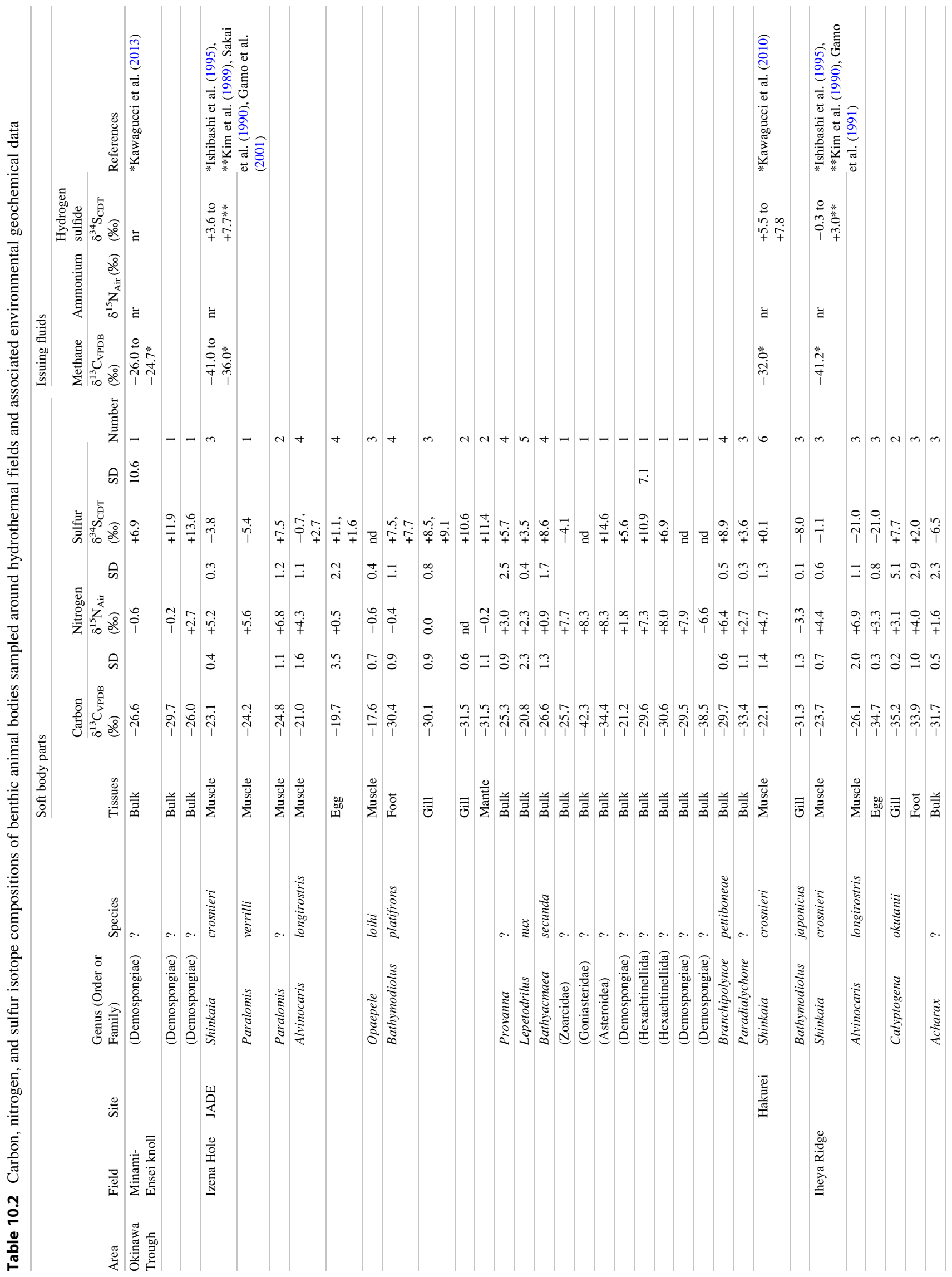




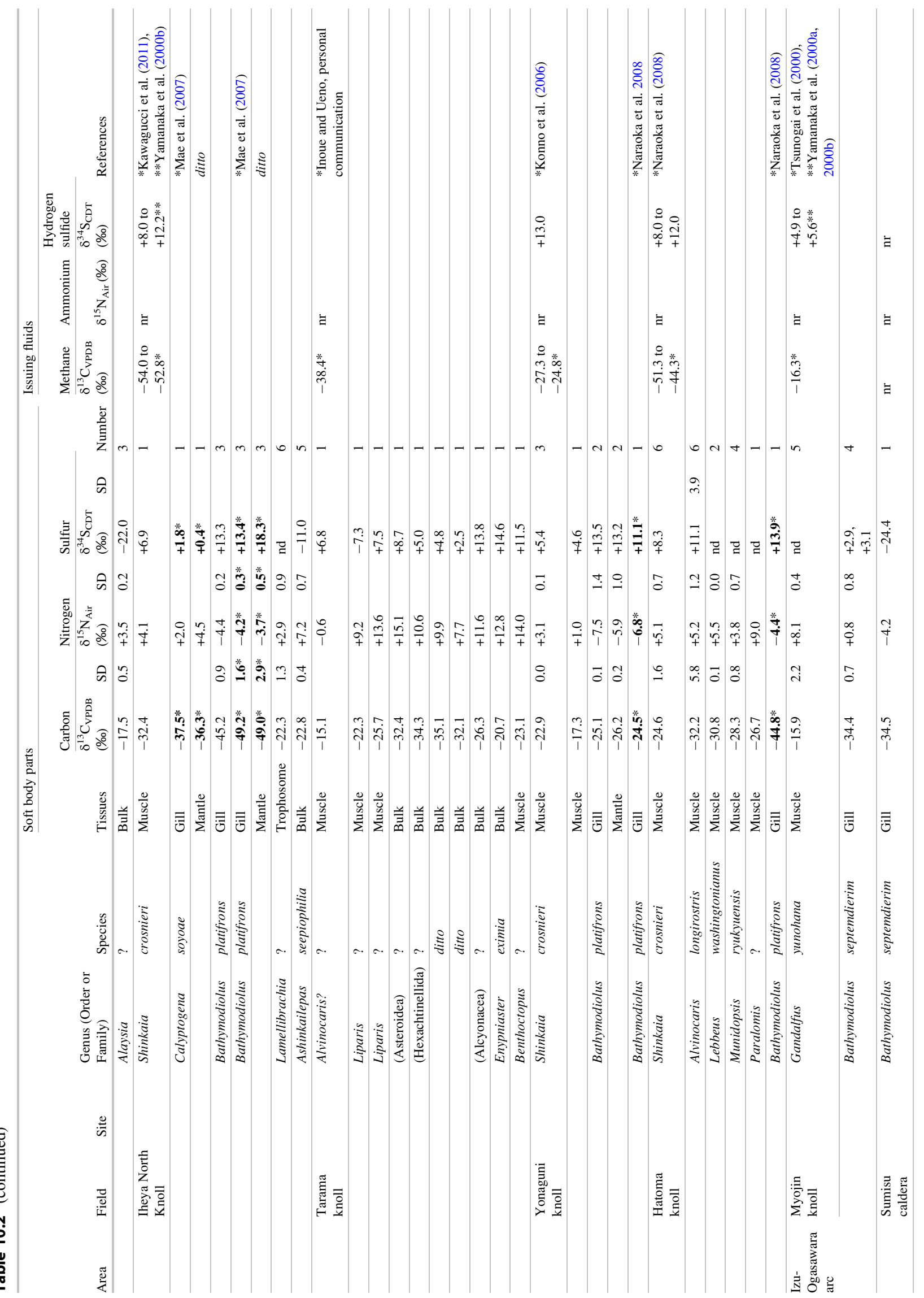




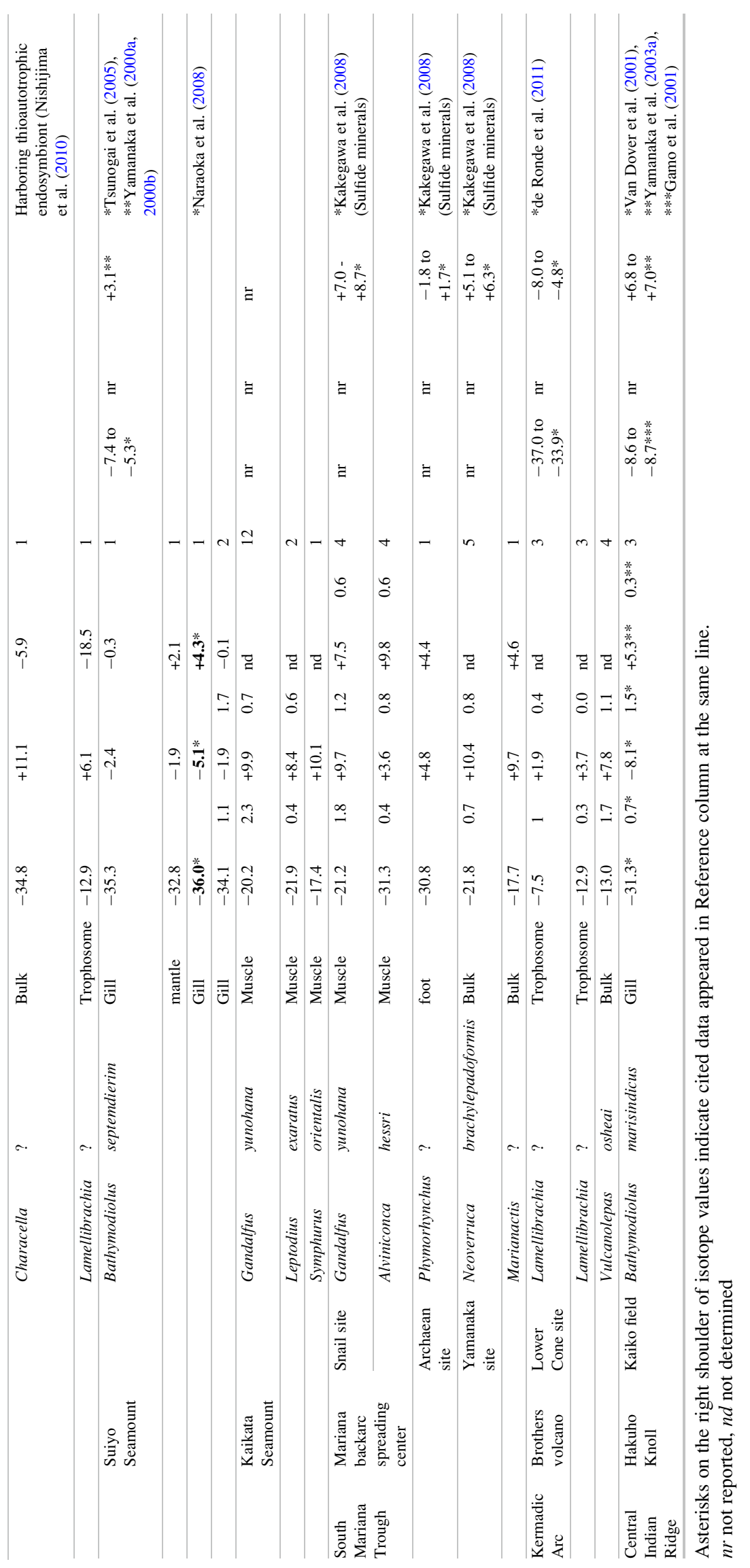




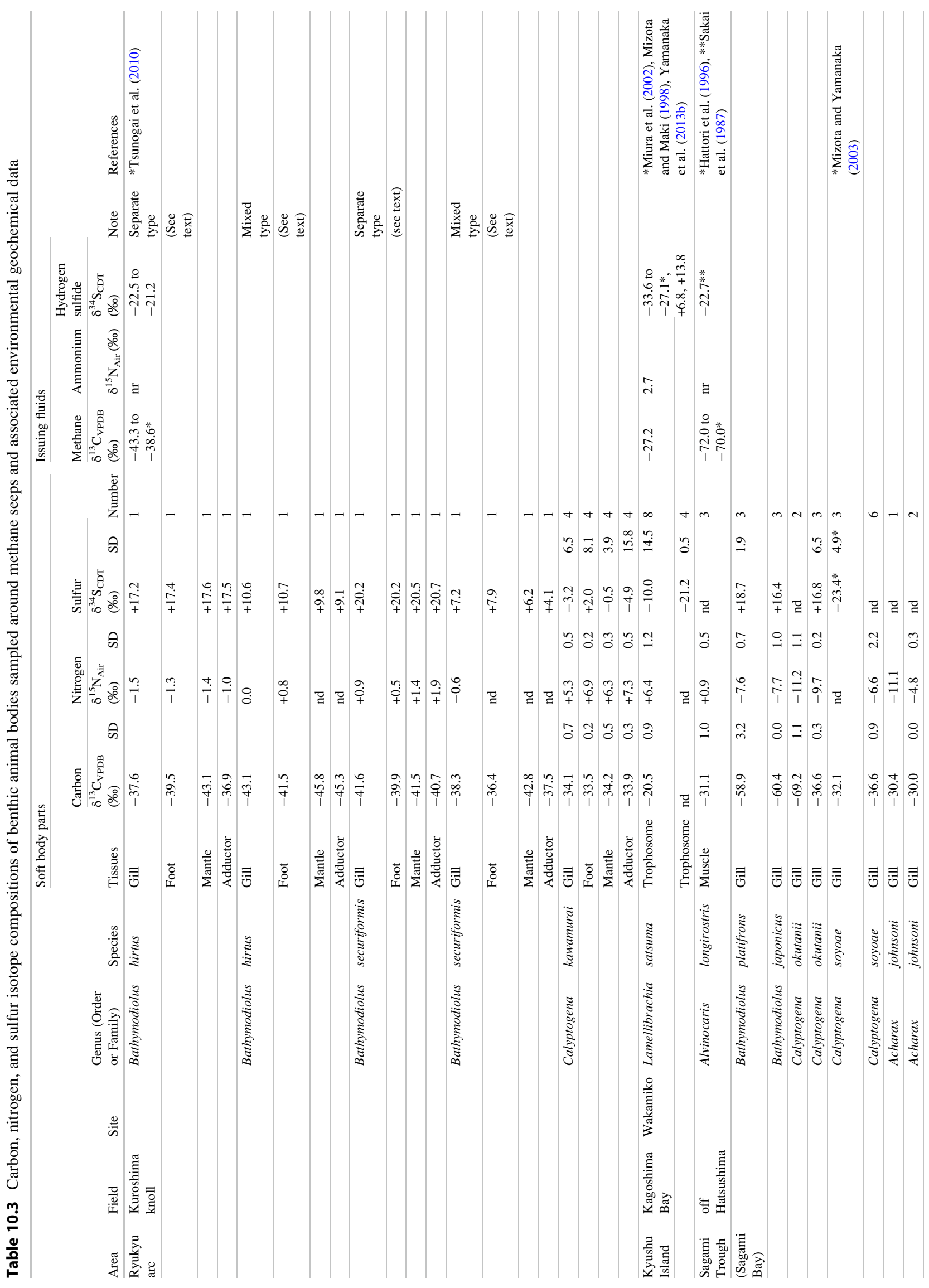




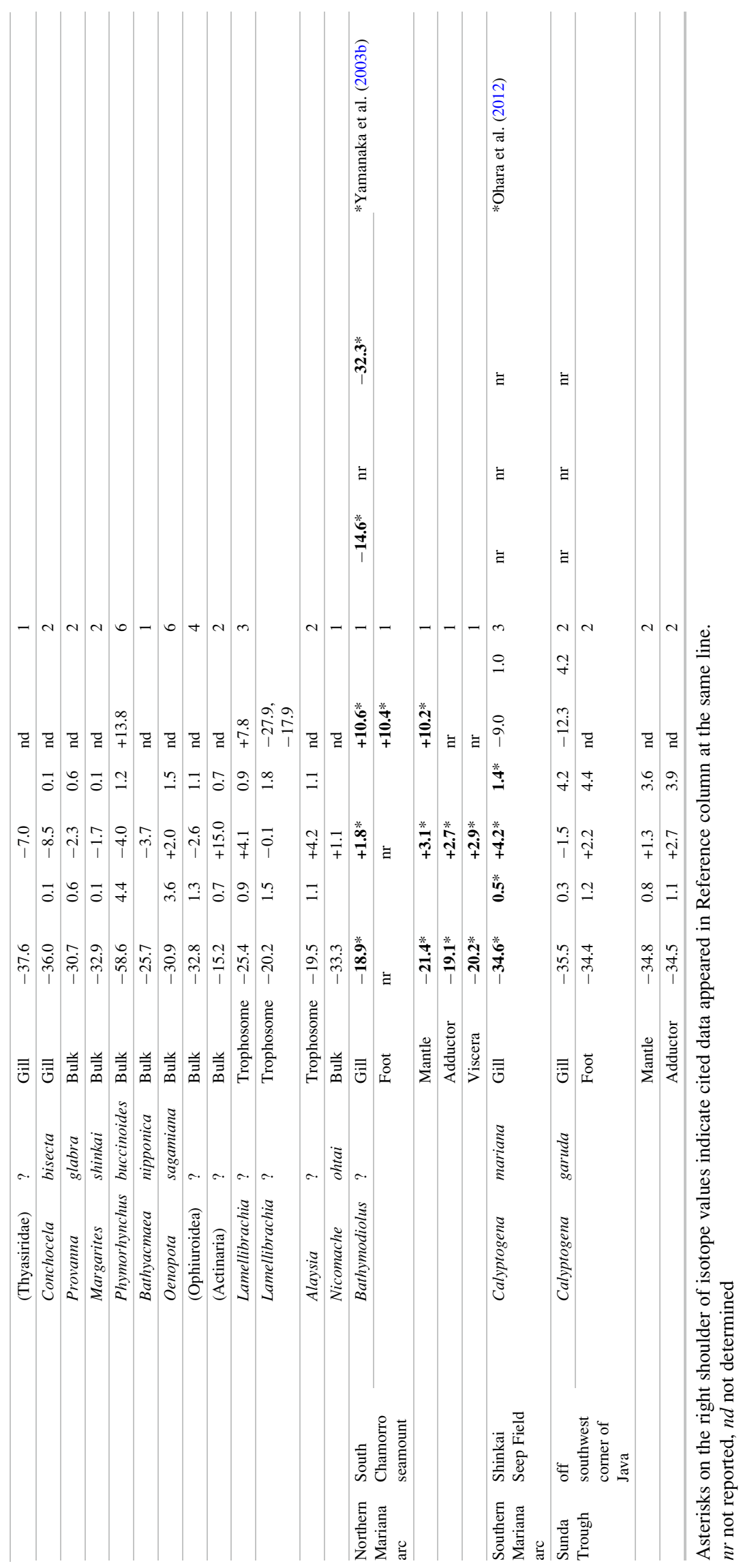


Fig. 10.2 Plot of carbon vs. nitrogen isotopic ratios for animal soft bodies from hydrothermal fields. Numerical data are shown in Table 10.2. Barnacles include Ashinkailepas and Neoverruca. Crustacean 1 includes two shrimps, Lebbeus and Opaepele, and three crabs, Munidopsis, Gandalfus, and Leptodius. Crustacean 2 includes the crab, Paralomis. Others include sea anemones, soft corals, and sea sponges. Abbreviations in the figures indicate the locations of the samples (red-colored abbreviations indicate sedimentstarved hydrothermal fields, see Table 10.1)

Fig. 10.3 Plot of carbon vs sulfur isotopic ratios for animal soft bodies from hydrothermal fields. Numerical data are shown in Table 10.2. Barnacles include Ashinkailepas and Neoverruca. Crustacean 1 includes two shrimps, Lebbeus and Opaepele, and three crabs, Munidopsis, Gandalfus, and Leptodius. Crustacean 2 includes the crab, Paralomis. Others include sea anemones, soft corals, and sea sponges. Abbreviations in the figures indicate the locations of the samples (red-colored abbreviations indicate sedimentstarved hydrothermal fields, see Table 10.1)
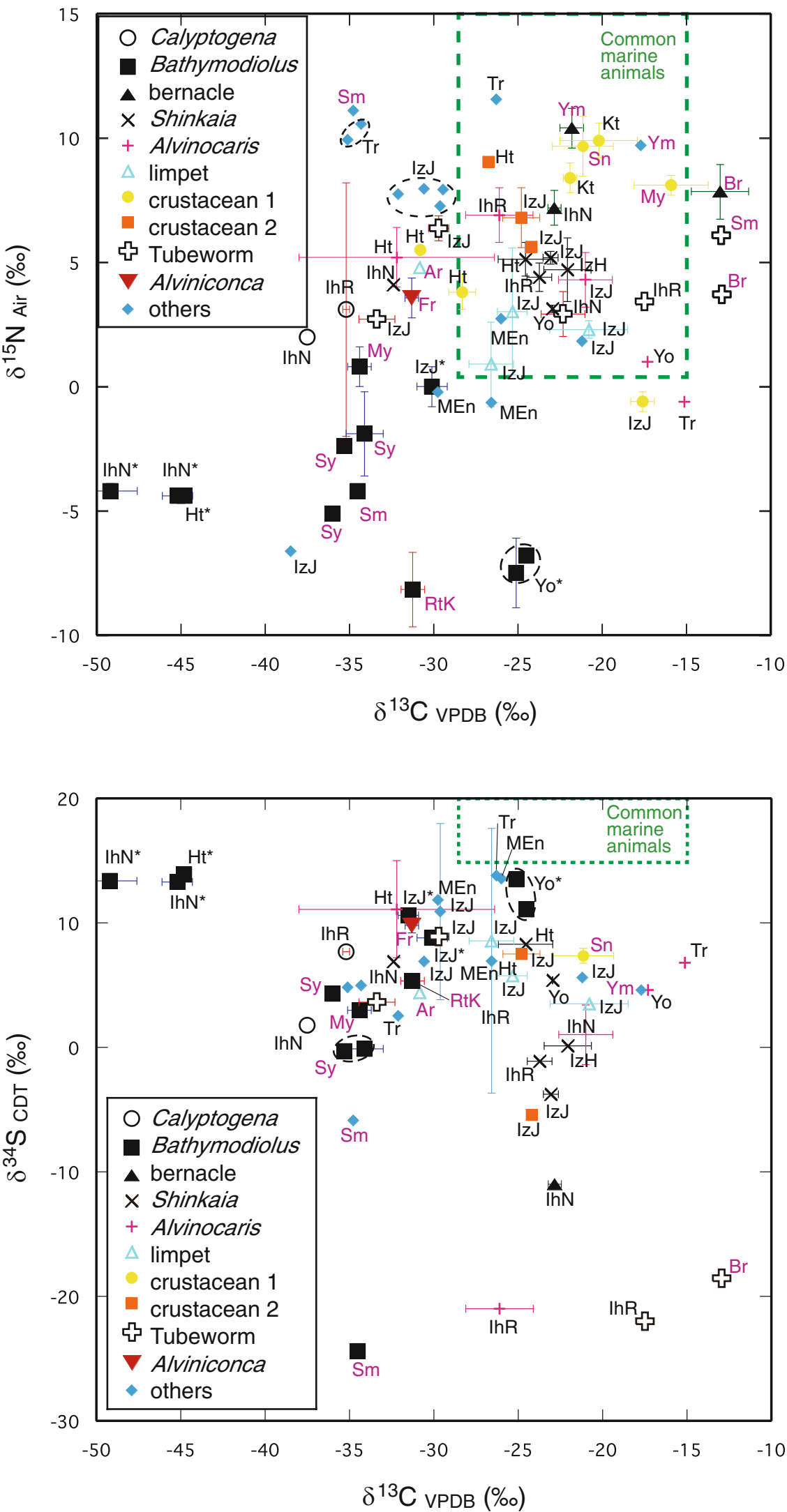
Fig. 10.4 Plot of carbon vs. nitrogen isotopic ratios of animal soft bodies from methane seep fields. Numerical data are shown in Table 10.3. Other bivalves include Thyasiridae, Solemyidae, and Thyasiridae groups. These bivalves harbor thioautotrophic endosymbiots in their gill tissues. Others include Alviniconca shrimp, Actiniaria sea anemone, and Ophiuroidea starfish. Abbreviations in the figures indicate the locations of the samples (see Table 10.1), and plots without abbreviations represent collections off Hatsushima, in Sagami Bay
Fig. 10.5 Plot of carbon vs. sulfur isotopic ratios of animal soft bodies from methane seep fields. Numerical data are shown in Table 10.3. Other bivalves include Thyasiridae, Solemyidae, and Thyasiridae groups. These bivalves harbor thioautotrophic endosymbiots in their gill tissues. Others include Alviniconca shrimp, Actiniaria sea anemone, and Ophiuroidea starfish. Abbreviations in the figures indicate the locations of the samples (see Table 10.1), and plots without abbreviations represent collections off Hatsushima, in Sagami Bay
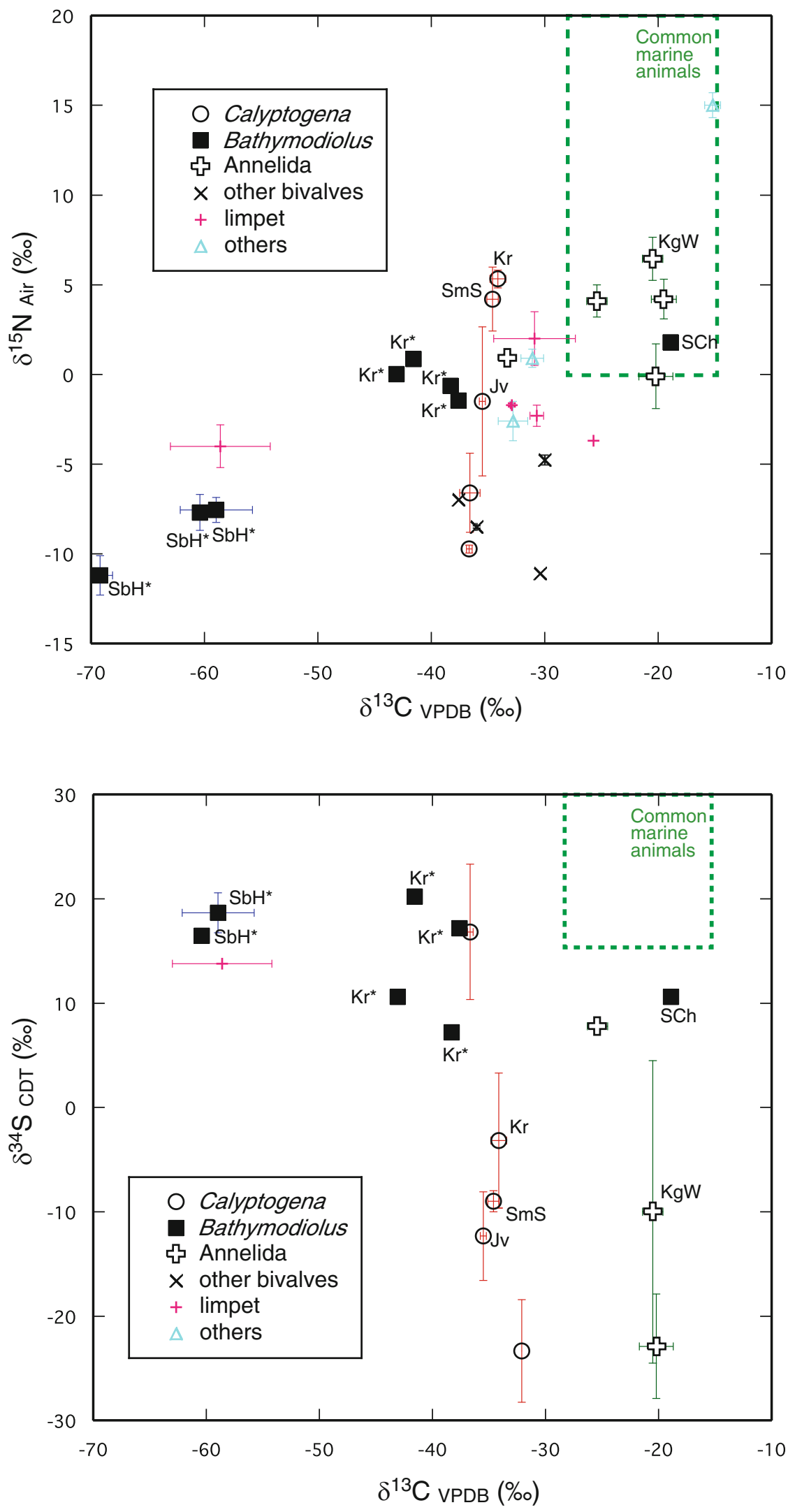
Fig. 10.6 Apparent differences between the $\delta^{34} S$ values of animal soft bodies and issuing hydrogen sulfide from hydrothermal fields. The two dotted lines indicate the possible range of variation in $\delta^{34} S$ values of hydrogen sulfide and kinetic isotope fractionation involved with its assimilation. Abbreviations indicate the sample locations shown in Table 10.1

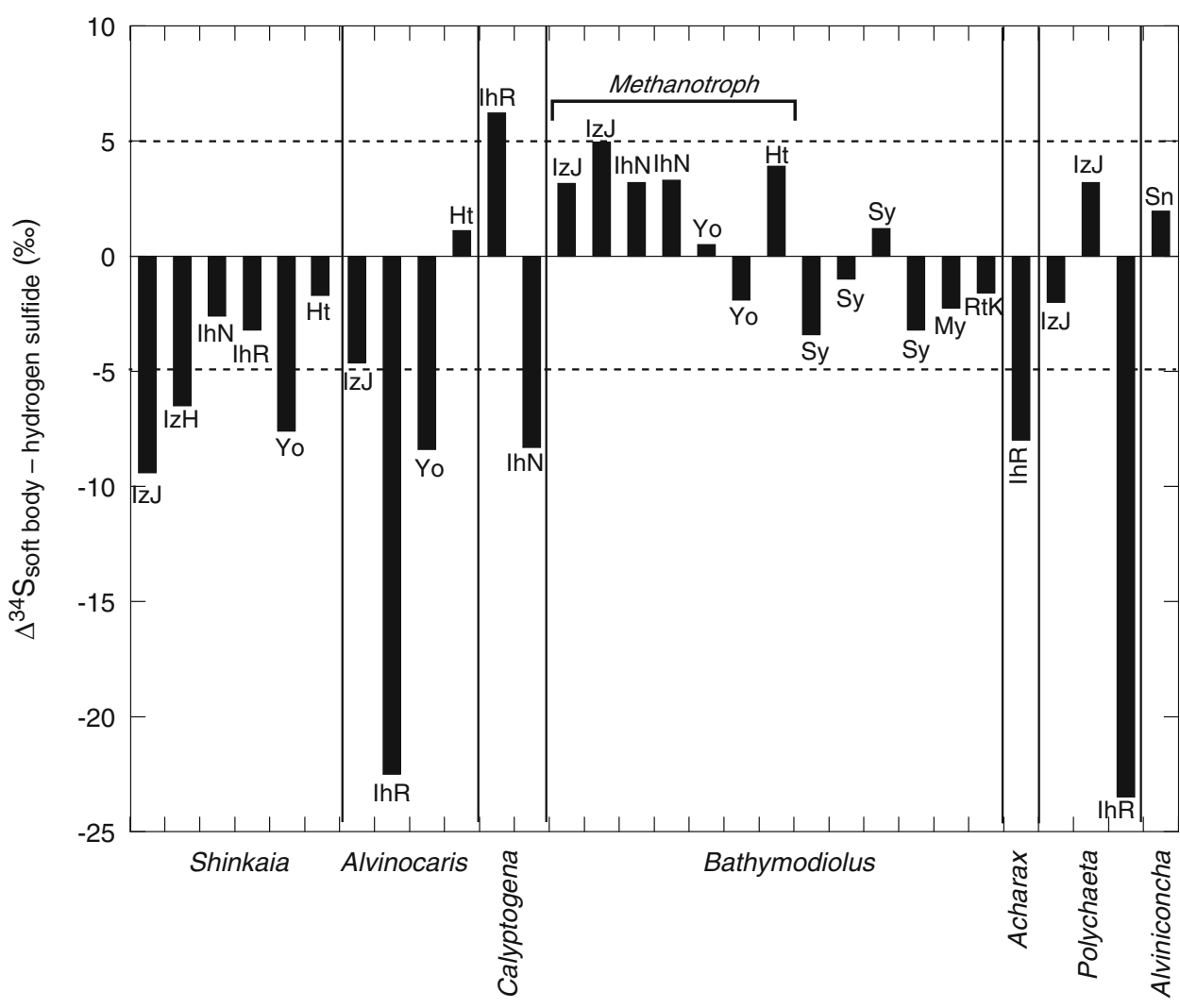

Fig. 10.7 Apparent differences between the $\delta^{34} \mathrm{~S}$ values of animal soft bodies from hydrothermal fields and seawater sulfate-sulfur $\left(\delta^{34} \mathrm{~S}=+21 \%\right.$ \%). The dotted line indicates the possible range of kinetic isotope fractionation involved in the incorporation and subsequent assimilation of sulfates. Abbreviations indicate the sample locations shown in Table 10.1

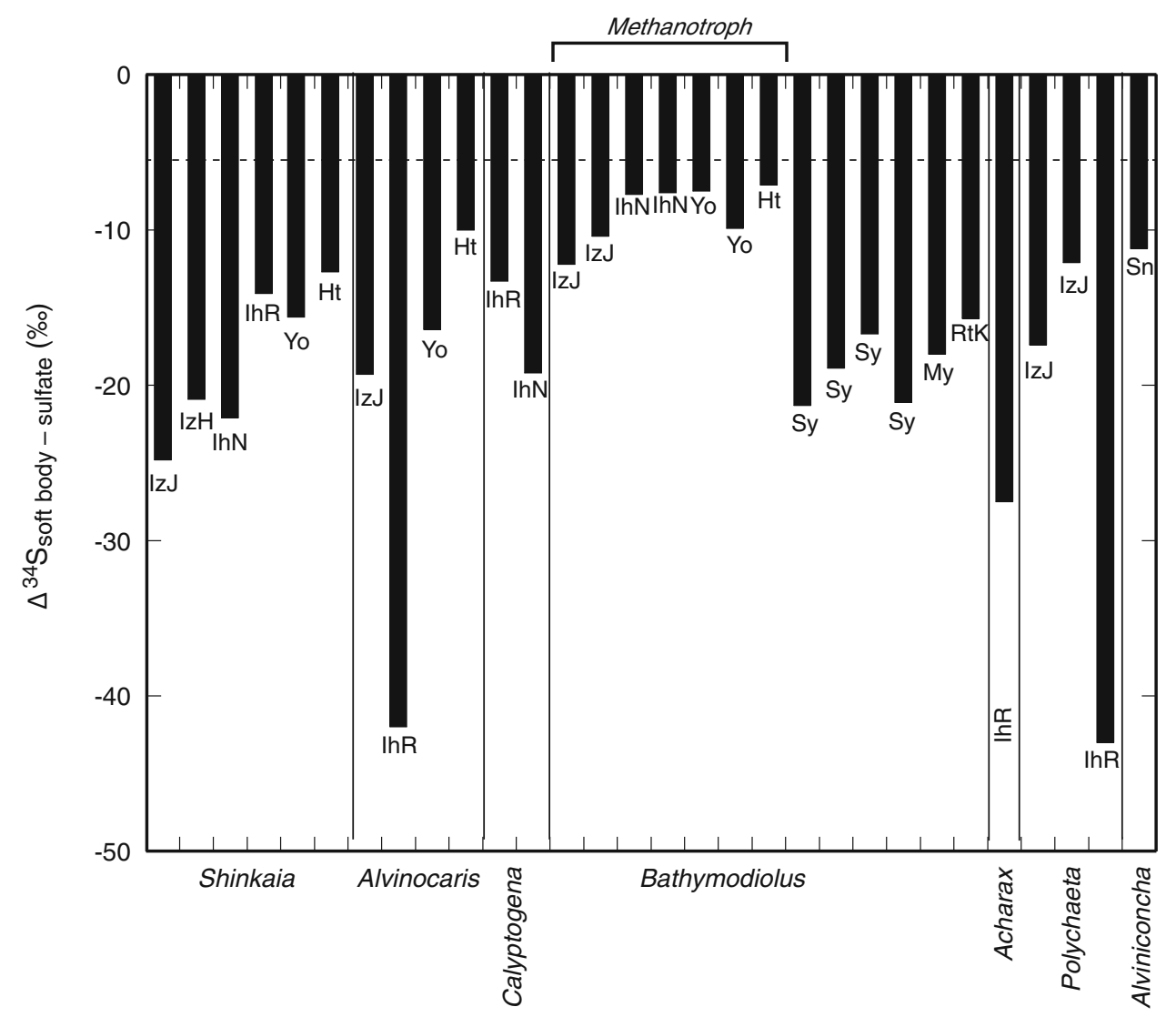


Fig. 10.8 Apparent differences between the $\delta^{34} S$ values of animal soft body parts obtained from methane seep areas and seawater sulfate-sulfur $\left(\delta^{34} \mathrm{~S}=+21 \%\right.$ ).

The dotted line indicates the possible range of kinetic isotope fractionation involved with assimilation of sulfate.

Abbreviations indicate the sample locations shown in Table 10.1

\subsubsection{Methane}

The $\delta^{13} \mathrm{C}$ values of dissolved methane in the venting fluids ranged from -54 to $-4 \%$ (Tables 10.2 and 10.3). Methanotrophic species, which are known to harbor methanotrophic endsymbionts, are expected to show $\delta^{13} \mathrm{C}$ values close to that of the associated methane. Apparent differences between $\delta^{13} \mathrm{C}$ values of animal soft tissues and the associated methane are shown in Figs. 10.9 and 10.10. Most animal samples showed higher $\delta^{13} \mathrm{C}$ values relative to those of the associated methane.

\subsection{Discussion}

\subsubsection{The Contribution of Thioautotrophic Nutrition to the Benthic Animal Community}

For benthic communities inhabiting the areas around hydrothermal vents and methane seeps, i.e., the discharge zone of TAIGA, major mechanisms that exploit their limited sulfur isotopic fractionation are considered to be a positive assimilation of sulfide-sulfur, since $\delta^{34} \mathrm{~S}$ values of sulfide are usually lower than $+12 \%$. As shown in
Figs. 10.3 and 10.5, many animal tissue samples had $\delta^{34} \mathrm{~S}$ values lower than $+15 \%$ o, suggesting that the animals rely nearly all or in part on thioautotrophic nutrition. Some animals (mostly mussels, such as Bathymodiolus japonicas, B. platifrons, B. hirtus, and B. securifornis), which have higher $\delta^{34} \mathrm{~S}$ values $(\geq+15 \%$ o), are known to harbor methanotrophic endosymbionts in their gill tissue (Fujiwara et al. 2000; Fujikura et al. 2003). These results are quite reasonable, since some of the methanotrophic mussels inhabiting the Okinawa Trough have $\delta^{34} \mathrm{~S}$ values of slightly less than $+14 \%$. Bathymodiolus mussels are expected to have preserved their ability to feed via filtration (Page et al. 1990, 1991). Therefore, these results may suggest positive assimilation of thioautotrophic nutrition via filter feeding. Mussels from South Chamorro serpentine seamount also had low $\delta^{34} \mathrm{~S}$ values $(\sim+10 \%)$. The mussels are considered to harbor both thioautotrophic and methanotrophic endosymbionts (i.e., dual symbiosis) (Yamanaka et al. 2003b). The other heterotrophs, except for vent and seep endemic species, also have $\delta^{34} \mathrm{~S}$ values of slightly $<+15 \%$ o (Figs. 10.3 and 10.5), indicating that thioautotrophic nutrition at the vent and seep fields prevails not only with the endemic animals, but also with diverse animals inhabiting areas around the fields. 


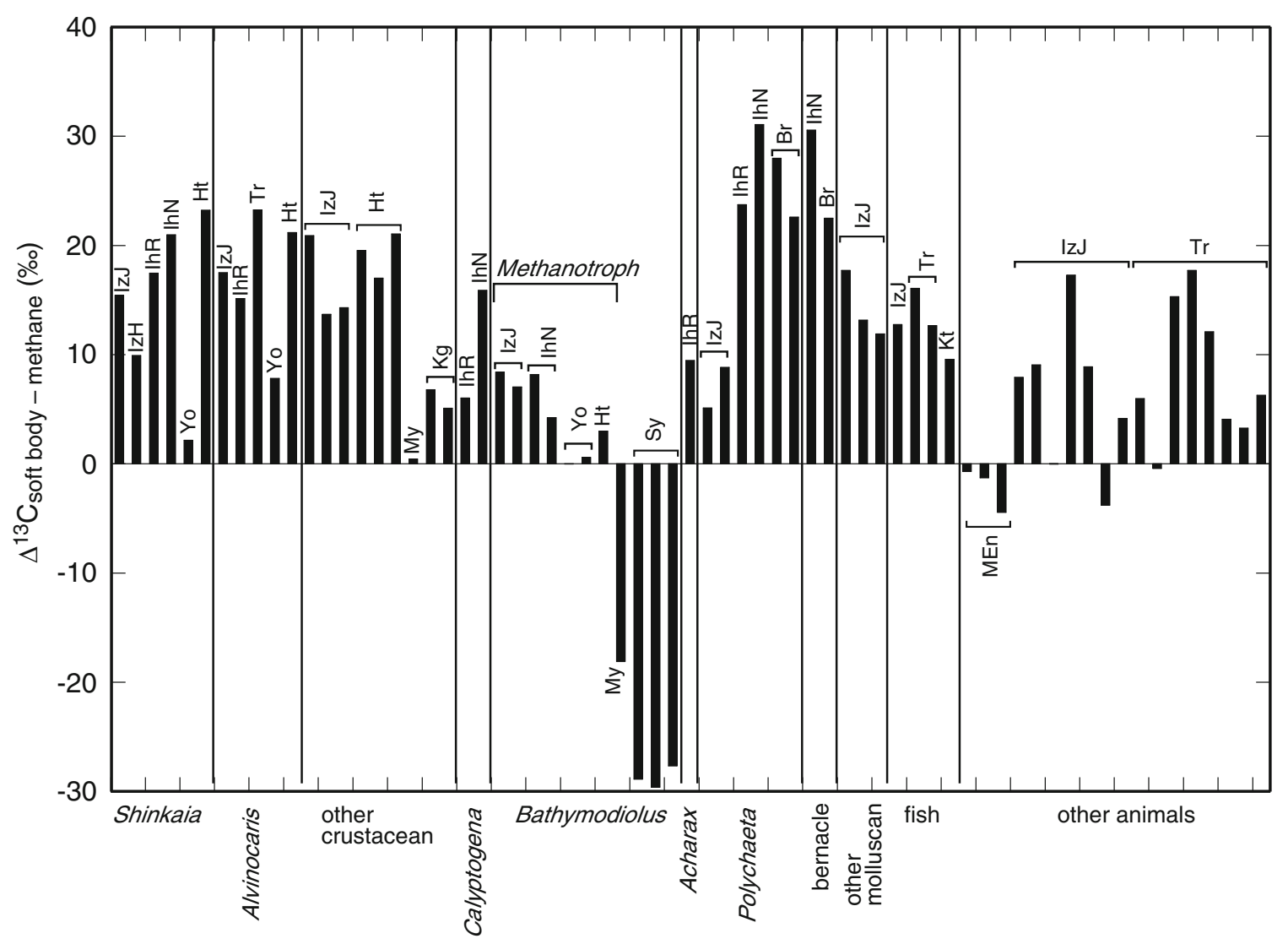

Fig. 10.9 Apparent differences between the $\delta^{13} \mathrm{C}$ values of animal soft body parts and associated methane obtained from hydrothermal areas. Abbreviations indicate the sample locations shown in Table 10.1

Fig. 10.10 Apparent isotopic fractionation of $\delta^{13} \mathrm{C}$ values of animal soft bodies and issuing methane from methane seep fields. The mussels harbor methanotrophic symbionts in their gill tissues. Abbreviations indicate the sample locations shown in Table 10.1. "Mix" indicates that the sample specimens form a mixed colony of $B$. hirtus and $B$. securiformis

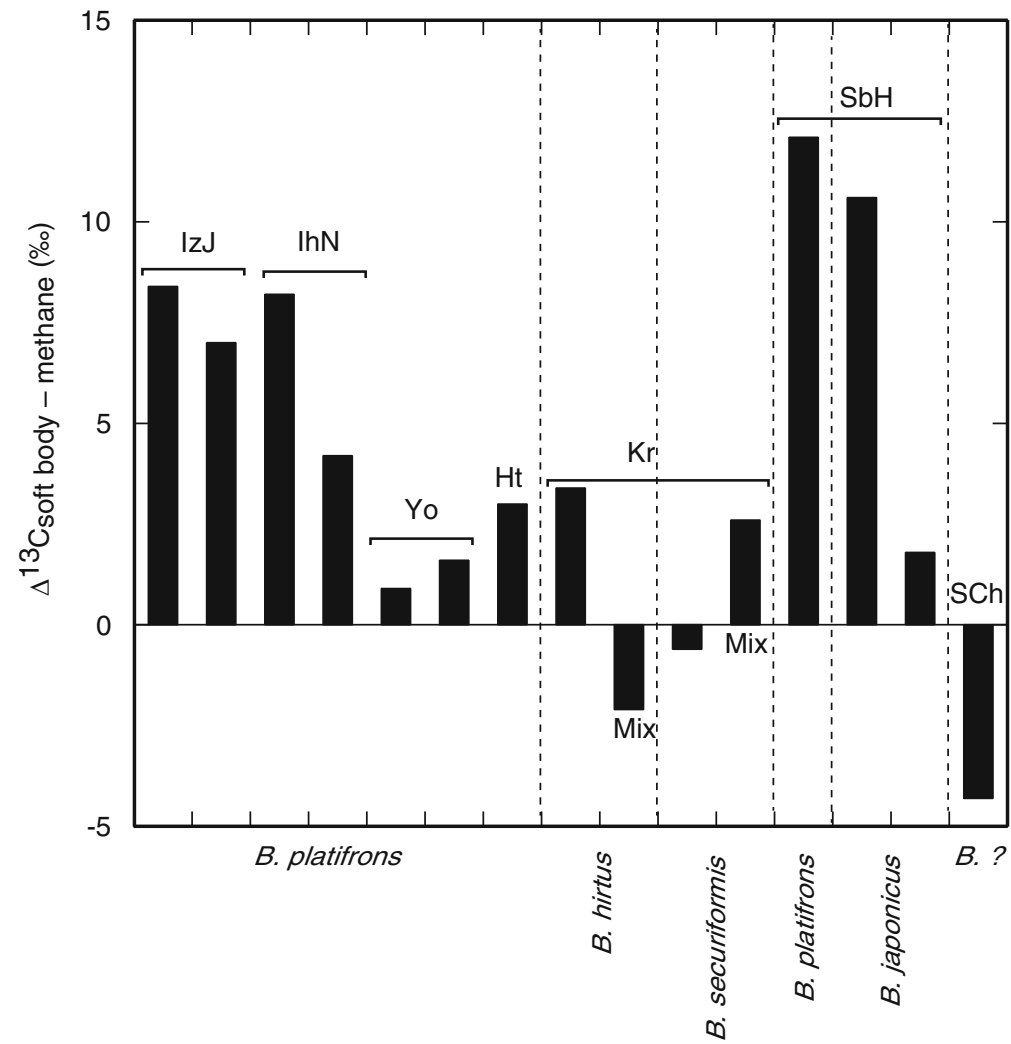


One group of Calyptogena soyoae from the off Hatsushima site showed quite high $\delta^{34} \mathrm{~S}$ values $(\sim+16.5 \pm 6.5 \%)$. Masuzawa (1996) reported similar high $\delta^{34} \mathrm{~S}$ values $(\sim+14 \%$ ) from other Calyptogena soyoae in the area, although the $\delta^{34} \mathrm{~S}$ value of hydrogen sulfide from that habitat has not been documented. The spatial distribution of $\delta^{34} \mathrm{~S}$ values for sedimentary sulfide is often heterogeneous within the anoxic environment (e.g., Yamanaka et al. 1999). Paired analysis of sulfur in clams and substrate sediments is required for further study.

The above results also suggest that the sediment-hosted hydrothermal vent and methane-rich seep fields provide thioautotrophic nutrition (i.e., sulfur-oxidizing bacteria and heterotrophic organisms that rely on them) derived from the suspended particles and detritus in the surface sediments. In fact, significant amounts of sulfur-oxidizing microbe cells have been identified in the bottom water around hydrothermal fields in the Okinawa Trough (Yanagawa et al. Chap. 6). Such high biomass flux of the sulfur-oxidizing microbes is supported by microbial sulfide production, suggesting that sub-seafloor bacterial sulfate reduction using methane or sedimentary organic matter as electron donors (Masuzawa et al. 1992) is quite active at the discharge zone of TAIGA.

From the above-mentioned stable isotopic data, it is possible to estimate the contribution of thioautotrophic nutrition to benthic animal communities. Nevertheless, the primary source of hydrogen sulfide is not only hydrothermal but also bacterial. The $\delta^{34} \mathrm{~S}$ values of bacterial hydrogen sulfide vary widely (e.g., Thode 1988). Therefore, it is difficult to accurately estimate the contribution of thioautotrophic nutrition. The $\delta^{34} \mathrm{~S}$ values for sulfur of animal soft tissue are less than $+10 \%$, indicative of a significant contribution from thioautotrophic nutrition.

\subsubsection{Variations in the Carbon Isotopic Ratios of the Benthic Animal Community}

The carbon isotopic ratios for the animal soft tissues varied widely (Figs. 10.2, 10.3, and 10.4, and Tables 10.2 and 10.3). This may reflect the variation in $\delta^{13} \mathrm{C}$ values of the methane ( -71 to $-6 \%$ o) issuing from hydrothermal vents and cold seeps. In particular, $\delta^{13} \mathrm{C}$ values of methanotrophic Bathymodiolus mussels varied widely, ranging from -70 to $-20 \%$. The $\delta^{13} \mathrm{C}$ values for most animal soft tissue samples were higher than those of the associated methane (Figs. 10.9 and 10.10). This can be explained by the following two scenarios: (1) the contribution of methane as a carbon source for chemosynthesis-based animals, except for methanotrophic species, is insignificant at many discharge zones or (2) the $\delta^{13} \mathrm{C}$ values of methane are increasing due to the selective incorporation of isotopically light methane during biological oxidation (e.g., Silverman and Oyama 1968) before delivery to methanotrophs.

In the former case (1), chemoautotrophs fix $\mathrm{CO}_{2}$ and therefore do not directly assimilate ${ }^{13} \mathrm{C}$-depleted methane. Dissolved inorganic carbon (mainly bicarbonate) is usually abundant in the bottom seawater. This means that the signature of ${ }^{13} \mathrm{C}$-depleted $\mathrm{CO}_{2}$ originating from ${ }^{13} \mathrm{C}$-depleted methane oxidation is difficult to detect. In the latter case (2), methane emitted at the sediment-hosted systems undergoes biological oxidation and incorporation during penetration of the sediments, resulting in methane that is enriched in ${ }^{13} \mathrm{C}$ relative to the primary source to be delivered to methanotrophic animals (mainly Bathymodiolus mussels).

Another plausible explanation for the methanotrophic species that are enriched in ${ }^{13} \mathrm{C}$, relative to the associated methane, is the heterotrophic assimilation of organic matter via filter feeding, as demonstrated by Page et al. (1990). The $\delta^{13} \mathrm{C}$ values of methane originating from pyrolysis of organic matter and microbial methanogenesis, relative to that of common organic matter, are usually depleted in ${ }^{13} \mathrm{C}$. Heterotrophic and thiotrophic animals are enriched in ${ }^{13} \mathrm{C}$ compared to methane from these sources. In these cases, the soft tissue is probably depleted in ${ }^{34} \mathrm{~S}$ due to the dependence on thioautotrophic nutrition. In fact, the mussels inhabiting the Okinawa Trough were slightly depleted in ${ }^{34} \mathrm{~S}$, suggesting a positive incorporation into thioautotrophic nutrition, as mentioned above.

On the other hand, some animal soft tissues depleted in ${ }^{13} \mathrm{C}$, relative to the associated methane (Figs. 10.9 and 10.10), were found at the field where emitted methane showed quite high $\delta^{13} \mathrm{C}$ values $(\geq-10 \%)$ in an abiotic source (the sediment-starved Myojin and Suiyo seamounts and serpentine-hosted South Chamorro seamount). Furthermore, the mussels of South Chamorro harbor thioautotrophic endsymbionts in addition to methanotrophs, which assimilate abiotic methane enriched in ${ }^{13} \mathrm{C}$. Therefore, resulting $\delta^{13} \mathrm{C}$ values of the mussels decreased relative to those of the associated methane. Its dual symbiosis has also been supported by their low $\delta^{34} \mathrm{~S}$ values $(+10.6 \%$ for gill tissues), relative to seawater-sulfate (Table 10.3).

Some thiotrophic vestimentiferan tubeworms have slightly higher $\delta^{13} \mathrm{C}$ values $(\geq-20 \%$ ). It is known that this animal has another carbon fixation pathway instead of the Calvin cycle (Nelson and Fisher 1995). For example, the rTCA cycle is a process that accompanies the insignificant isotopic fractionation during carbon fixation (Markert et al. 2007). Some heterotrophic animals that have high $\delta^{13} \mathrm{C}$ values may feed via mechanisms similar to the tubeworms.

One species of limpet, Phymorhynchus buccinoides, obtained from off Hatsushima, has been reported to feed predominantly on the dead bodies of Bathymodiolus mussels (Fujikura et al. 2009). Their $\delta^{13} \mathrm{C}$ values are significantly lower $(\sim-60 \%$, Table 10.3$)$ than those of the other 
heterotrophs. Although such specific heterotrophs relying on a single vent or seep endemic species have rarely been reported until recently (Van Dover 2000), carnivores, scavengers, and parasites relying on a single vent or seep animals are likely found in the vent and seep communities. In fact, parasitical polychaeta, Branchipolynoe pettiboneae, collected from inside the shell of Bathymodiolus mussels obtained from JADE site, Izena Hole have similar $\delta^{13} \mathrm{C}$ and $\delta^{34} \mathrm{~S}$ values to the associate mussels with $\sim 6 \%$ enriched in ${ }^{15} \mathrm{~N}$ (Table 10.2). With further study, these animals will continue to be identified.

\subsubsection{Nitrogen Isotopic Ratios of Symbiotic Bivalves}

Nitrogen isotopic ratios of animals have been used for the estimation of trophic levels in studies of food web structures (Minagawa and Wada 1984). Usually, higher trophic levels are believed to have elevated $\delta^{15} \mathrm{~N}$ values. Such enrichment in ${ }^{15} \mathrm{~N}$ with increasing trophic level is also common in vent and seep communities, while symbiotic mussels, such as Calyptogena clams and Bathymodiolus mussels, still have significantly low $\delta^{15} \mathrm{~N}$ values (Figs. 10.2 and 10.4). Such trends were recognized in early studies of the chemosynthesis-based animal community, and the reasons for such low values have been debated (e.g., Van Dover 2000), although the detailed mechanism is not well understood. Some plausible explanations have been proposed, e.g., assimilation of ammonium, which prevails in anoxic sediments, may be an important process. During the assimilation of ammonium nutrition, isotopic fractionation may occur (e.g., Hübner 1986; Yoneyama et al. 1993; Lee and Childress 1994). Isotopic fractionation during the assimilation of ammonium depends on its concentration and the types of enzymes used in ammonium assimilation. The reported values range from -20 to $+4 \%\left(\delta^{15} \mathrm{~N}_{\text {ammonium }}-\right.$ $\delta^{15} \mathrm{~N}_{\text {organism}}$ ) (Hübner 1986; Yoneyama et al. 1993). The $\delta^{13} \mathrm{C}$ and $\delta^{15} \mathrm{~N}$ values of most animal tissues, especially the Bathymodiolus mussels inhabiting the methane seeps, are highly correlated $\left(\mathrm{R}^{2}=0.85\right)$ (Fig. 10.4). The increasing $\delta^{13} \mathrm{C}$ values may be due to isotopic fractionation during microbial oxidation and/or assimilation of methane nutrition. The $\delta^{15} \mathrm{~N}$ values of source ammonium are also plausibly increased by microbial consumption, because isotopically light ammonium in preferentially incorporated. Therefore, this implies that $\delta^{15} \mathrm{~N}$ values of ammonium increase together with $\delta^{13} \mathrm{C}$ values of methane due to bacterial isotopic discrimination until the ammonium in source fluids reaches the mussel habitat.

Among the seep fields, the carbon isotopic ratios of methane have reflected the methane origin. However, in our limited data set, Bathymodiolus mussels obtained from methane seeps off Hatsushima showed a positive correlation between carbon and nitrogen isotopic ratios. This implies that the $\delta^{13} \mathrm{C}$ and $\delta^{15} \mathrm{~N}$ values of the mussels reflect subsurface microbial processes, which preferentially incorporate isotopically light methane together with ammonium. Ammonium is a plausible source of nitrogen nutrition for methanotrophic communities. Due to a lack of isotopic data for ammonium in this habitat, further studies are needed.

\subsubsection{Competition for Energy Sources and the Role of Filter Feeding by Bathymodiolus Mussels}

Two Bathymodiolus species (B. hirtus and B. securiformis) have been observed at the Kuroshima knoll seep site, where they usually form small colonies composed of one species (separate-type). Nevertheless, some colonies form a mixture of both species (mixed-type). Both species are believed to harbor methanotrophic bacteria as their sole endosymbionts (Fujikura et al. 2003). In fact, sulfur isotopic compositions for specimens from separate-type colonies show a range typical of methanotrophic animals $\left(\delta^{34} \mathrm{~S} \geq+15 \%\right)$. The $\delta^{34} \mathrm{~S}$ values of specimens from the mixed-type colonies are about $10 \%$ lower than those from the separate-type colonies. Both carbon and nitrogen isotopic ratios for two types of samples are relatively similar. Such low $\delta^{34} \mathrm{~S}$ values may be due to the assimilation of thioautotrophic nutrition via filter feeding. Mussels of the mixed-type colonies may compete with each other for methane nutrition as an energy source. They may compensate for the shortage of methanotrophic nutrition derived from the endosymbionts by filter feeding.

\subsection{Summary}

Benthic animal communities supported by thioautotrophic and methanotrophic nourishment are widely distributed over the discharge area of TAIGA, and they have high biodiversity including common marine benthos. As we have summarized the nutritional sources of the benthic animals discussed in this study in the Supplementary document (Suppl. 10.1), microbial methane and hydrogen sulfide generated within the sedimentary layer are important energy sources for microbes, in addition to abiogenic methane and hydrogen sulfide dissolved in the issuing fluids. Although some hydrothermal vent and methane seep endemic species harbor endosymbiotic bacteria and lack digestive organs, Bathymodiolus mussels still have ability to feed in the Okinawa Trough and some other methane seep fields. The data suggest that the sediment covered discharge area of TAIGA is also abundant in suspended and/or free-living 
microbes, namely thioautotrophs, which support huge biomass production and biodiversity on the deep seafloor.

Acknowledgements We are grateful to Drs. K. Fujikura, Y. Fujiwara, S. Tsuchida, H. Watanabe, D. J. Lindsay, F. Inagaki, and Y. Ohara for providing the animal samples used in this study. We are grateful to Drs. K. Yanagi, S. Kojima, T. Okutani, and T. Yamamoto for identification of the sample animals. We are also indebted to Professor H. Chiba and Dr. S. Kawaguchi for their very useful comments. All of the fluid, water, and chimney samples were obtained through the cooperative efforts of the operation teams of the ROVs HyperDolphin, Dolphin $3 k$, Kaiko, and ROPOS, the DSV Shinkai 2000 and 6500, and the captain and crew of the support ships R/Vs Natsushima, Kaiyo, Yokosuka, and Thomas Tompson, to whom we extend our heartfelt thanks. This research was supported by the Ministry of Education, Culture, Sports, Science and Technology of Japan through a Special Coordination Fund 'TAIGA' project (New Scientific Research on Innovative Areas, 20109005) and the Archaean Park Project (International Research Project on Interaction between Sub-Vent Biosphere and Geo-Environments).

Open Access This chapter is distributed under the terms of the Creative Commons Attribution Noncommercial License, which permits any noncommercial use, distribution, and reproduction in any medium, provided the original author(s) and source are credited.

\section{References}

Berndt ME, Allen DE, Seyfried WE (1996) Reduction of $\mathrm{CO}_{2}$ during serpentinization of olivine at $300{ }^{\circ} \mathrm{C}$ and 500 bar. Geology 24:351-354

Canfield DE (2001) Biogeochemistry of sulfur isotopes, in stable isotope geochemistry. In: Valley JW, Cole DR (eds) Reviews in mineralogy and geochemistry, vol 43. Mineralogical Society of America, pp 607-636. doi:10.2138/gsrmg.43.1.607

Carpenter EJ, Harvey HR, Fry B, Capone DG (1997) Biogeochemical tracers of the marine cyanobacterium Trichodes- mium. Deep Sea Res Part 1 Oceanogr Res Pap 44(1):27-38. doi:10.1016/S09670637(96)00091-X

de Ronde CEJ, Massoth GJ, Butterfield DA, Christenson BW, Ishibashi J, Ditchburn RG, Hannington MD, Brathwaite RL, Lupton JE, Kamenetsky VS, Graham IJ, Zellmer GF, Dziak RP, Embley RW, Dekov VM, Munnik F, Lahr J, Evans LJ, Takai K (2011) Submarine hydrothermal activity and gold-rich mineralization at Brothers Volcano, Kermadec Arc, New Zealand. Miner Deposita 46:541-584. doi:10.1007/s00126-011-0345-8

Fiala-Médioni A, Boulègue J, Ohta S, Felbeck H, Mariotti A (1993) Source of energy sustaining the Calyptogena populations from deep trenches in subduction zones off Japan. Deep Sea Res Part I 40:1242-1258. doi:10.1016/0967-0637(93)90136-Q

Fisher CR, Childress JJ, Macko SA, Brooks JM (1994) Nutritional interactions in Galapagos Rift hydrothermal vent communities: inferences from stable carbon and nitrogen isotope analyses. Mar Ecol Prog Ser 103:45-55. doi:10.3354/meps103045

Fry B, Gest H, Hayes JM (1983) Sulfur isotopic compositions of deepsea hydrothermal vent animals. Nature 306:51-52

Fujikura K, Aoki M, Fujiwara Y, Ichibayashi S, Imamura M, Ishibashi J, Iwase R, Kato K, Kosaka A, Machiyama H, Miyake H, Miyazaki J, Mizota C, Morimoto Y, Naganuma T, Nakayama N, Okamoto K, Okoshi K, Sato-Okoshi W, Okutani T, Satoh T, Toth LG, Tsuchida S, Wakamatsu M, Watanabe H, Yamanaka T, Yamamoto H (2003) Report on investigation of vent and methane seep ecosystems by the crewed submersible 'Shinkai 2000' and the ROV 'Dolphin 3 K' on the Hatoma and the Kuroshima Knolls, the Nansei-shoto area, JAMSTEC. J Deep Sea Res 22:21-30 (in Japanese with English abstract)

Fujikura K, Sasaki T, Yamanaka T, Yoshida T (2009) Turrids whelk, Phymorhynchus buccinoides feeds on Bathymodiolus mussels at a seep site in Sagami Bay, Japan. Plankton Benthos Res 4(1):23-30

Fujikura K, Okutani T, Maruyama T (2012) Deep-sea Life: Biological observations using research submersibles, 2nd edn. Toukai University Press, Toukai (in Japanese with English captions)

Fujiwara Y, Takai K, Uematsu K, Tsuchida S, Hunt JC, Hashimoto J (2000) Phylogenetic characterization of endosymbionts in three hydrothermal vent mussels: influence on host distributions. Mar Ecol Prog Ser 208:147-155. doi:10.3354/meps208147

Gamo T, Sakai H, Kim ES, Shitashima K, Ishibashi J (1991) High alkalinity due to sulfate reduction in the clam hydrothermal field, Okinawa trough. Earth Planet Sci Lett 107:328-338

Gamo T, Chiba H, Yamanaka T, Okudaira T, Hashimoto J, Tsuchida S, Ishibashi J, Kataoka S, Tsunogai U, Kouzuma F, Okamura K, Sano Y, Shinjo R (2001) Chemical characteristics of newly discovered black smoker fluids and associated hydrothermal plumes at the Rodriguez Triple Junction, Central Indian Ridge. Earth Planet Sci Lett 193:371-379. doi:10.1016/S0012-821X(01)00511-8

Glasby GP, Iizasa K, Yuasa M, Usui A (2000) Submarine hydrothermal mineralization on the Izu-Bonin Arc, south of Japan: an overview. Mar Georesources Geotechnol 18(2):141-176. doi:10.1080/ 10641190009353785

Hashimoto J, Ohta S, Gamo T, Chiba H, Yamaguchi T, Tsuchida S, Okudaira T, Watabe H, Yamanaka T, Kitazawa M (2001) First hydrothermal vent communities from the Indian Ocean Discovered. Zool Sci 18(5):717-721. doi:10.2108/zsj.18.717

Hattori M, Kanie Y, Oba T, Akimoto K (1996) Environmental conditions of carbonates and chemosynthetic animal communities associated with cold seepage zones along the subduction zone in Sagami Bay, central Japan. Kaseki 60:13-22 (in Japanese with English abstract and captions)

Hübner H (1986) Isotope effects on nitrogen in the soil and biosphere. In: Fritz P, Fontes JC (eds) Handbook of environmental isotope geochemistry, vol 2. Elsevier, Amsterdam, pp 361-425

Iizasa K (1993) Assessment of the hydrothermal contribution to seafloor sediments in the Myojinsho submarine caldera, ShichitoIwojima ridge, Izu-Ogasawara arc, Japan. Mar Geol 114 (1-2):119-132. doi:10.1016/0025-3227(93)90043-U

Ishibashi J, Toki T (2012) Chemistry of deep-sea. In: Fujikura K, Okutani T, Maruyama T (eds) Deep-sea life: biological observations using research submersibles, 2 nd edn. Toukai University Press, Toukai, pp 10-23 (in Japanese with English captions)

Ishibashi J, Urabe T (1995) Hydrothermal activity related to arc-backarc magmatism in the western Pacific. In: Taylor B (ed) Backarc basins: tectonics and magmatism. Plenum, New York, pp 451-495

Ishibashi J, Sano Y, Wakita H, Gamo T, Tsutsumi M, Sakai H (1995) Helium and carbon geochemistry of hydrothermal fluids from the Mid-Okinawa Trough Back Arc Basin, southwest of Japan. Chem Geol 123(1-4):1-15. doi:10.1016/0009-2541(95)00051-M

Kakegawa T, Utsumi M, Marumo K (2008) Geochemistry of sulfide chimneys and basement pillow lavas at the Southern Mariana Trough (12.55 degrees N-12.58 degrees N). Resource Geol 58(3):249-266. doi:10.101/j.1751-3928.2008.00060.x

Kato S, Yanagawa K, Sunamura M, Takano Y, Ishibashi J, Kakegawa T, Utsumi M, Yamanaka T, Toki T, Noguchi T, Kobayashi K, Moroi A, Kimura H, Kawarabayasi Y, Marumo K, Urabe T, Yamagishi A (2009) Abundance of Zetaproteobacteria within crustal fluids in back-arc hydrothermal fields of the Southern Mariana Trough. Environ Microbiol 11(12):3210-3222. doi:10. 1111/j.1462-2920.2009.02031.x

Kawagucci S, Shirai K, Lan TF, Takahata N, Tsunogai U, Sano Y, Gamo T (2010) Gas geochemical characteristics of hydrothermal 
plumes at the HAKUREI and JADE vent sites, the Izena Cauldron, Okinawa Trough. Geochem J 44:507-518

Kawagucci S, Ueno Y, Takai K, Toki T, Ito M, Inoue K, Makabe A, Yoshida N, Muramatsu Y, Takahata N, Sano Y, Narita T, Teranishi G, Obata H, Nakagawa S, Nunoura T, Gamo T (2013) Geochemical origin of hydrothermal fluid methane in sediment-associated fields and its relevance to the geographical distribution of whole hydrothermal circulation. Chem Geol 339:213-225. doi:10.1016/j. chemgeo.2012.05.003

Kelley DS, Karson JA, Früh-Green GL, Yoerger D, Shank TM, Butterfield DA, Hayes JM, Schrenk MO, Olson E, Proskurowski G, Jakuba M, Bradley A, Larson B, Ludwig K, Glickson D, Buckman K, Bradley AS, Brazelton WJ, Roe K, Elend MJ, Delacour A, Bernasconi SM, Lilley MD, Baross JA, Summons RE, Sylva SP (2005) A Serpentinite-hosted ecosystem: the lost city hydrothermal field. Science 307:1428-1434.

Kennicutt MC II, Burke RA Jr, MacDonald IR, Brooks JM, Denoux GJ, Macko SA (1992) Stable isotope partitioning in seep and vent organisms - chemical and ecological significance. Chem Geol 101:293-310. doi:10.1016/0009-2541(92)90009-T

Kim ES, Sakai H, Hashimoto J, Yanagisawa F, Ohta S (1989) Sulfur isotopic-ratios of hydrothermal vent-animals at Ogasawara Arc and Mid-Okinawa Trough - evidence for microbial origin of hydrogen sulfide at low-temperature submarine hydrothermal areas. Geochem J 23:195-208

Kim ES, Sakai H, Gamo T, Hashimoto J, Ohta S, Yanagisawa F (1990) Carbon, nitrogen and sulfur isotopic ratios in hydrothermal vent animals from the mid-Okinawa Trough. JAMSTEC Deesea res 6:129-137 (in Japanese with English abstract and captions)

Konno U, Tsunogai U, Nakagawa F, Nakaseama M, Ishibashi J, Nunoura T, Nakamura K (2006) Liquid $\mathrm{CO}_{2}$ venting on the seafloor: Yonaguni Knoll IV hydrothermal system, Okinawa Trough. Geophys Res Lett 33, L16607. doi:10.1029/2006GL026115

Lee RW, Childress JJ (1994) Assimilation of inorganic nitrogen by marine invertebrates and their chemoautotrophic and methanotrophic symbionts. Appl Environ Microbiol 60:1852-1858

Letouzey J, Kimura M (1986) The Okinawa Trough: genesis of a backarc basin developing along a continental margin. Tectonophysics 125:209-230

Mae A, Yamanaka T, Shimoyama S (2007) Stable isotope evidence for identification of chemosynthesis-based fossil bivalves associated with cold-seepages. Palaeogeogr Palaeoclimatol Palaeoecol 245:411-420. doi:10.1016/j.palaeo.2006.09.003

Markert S, Arndt C, Felbeck H, Becher D, Sievert SM, Hugler M, Albrecht D, Robidart J, Bench S, Feldman RA, Hecker M, Schweder T (2007) Physiological proteomics of the uncultured endosymbiont of Riftia pachyptila. Science 315:247-250. doi:10. 1126/science. 1132913

Masuzawa T (1996) Cycling and isotopic composition of sulfur in deep sea cold seep communities. Gekkan Chikyu Gohgai 16:81-86 (in Japanese)

Masuzawa T, Handa N, Kitagawa H, Kusakabe M (1992) Sulfate reduction using methane in sediments beneath a bathyal "cold seep" giant clam community off Hatsushima Island, Sagami Bay, Japan. Earth Planet Sci Lett 110(1-4):39-50. doi:10.1016/0012821X(92)90037-V

Minagawa M, Wada E (1984) Stepwise enrichment of ${ }^{15} \mathrm{~N}$ along food chains: further evidence and the relation between $\delta^{15} \mathrm{~N}$ and animal age. Geochim Cosmochim Acta 48:1135-1140. doi:10.1016/00167037(84)90204-7

Miura T, Nedachi M, Hashimoto J (2002) Sulphur sources for chemoautotrophic nutrition of shallow water vestimentiferan tubeworm in Kagoshima Bay. J Mar Biol Assoc UK 82:537-540. doi:10.1017/ S0025315402005854

Mizota C, Yamanaka T (2003) Strategic adaptation of a deep-sea, chemosynthesis-based animal community: an evaluation based on soft body part carbon, nitrogen, and sulfur isotopic signatures. Jpn J Benthol 58:56-69 (in Japanese with English abstract)

Mizota C, Maki Y (1998) Sulfur isotopic variations in soft tissues of Calyptogena soyoae from Sagami Bay, central Japan. Geochem J $32: 421-425$

Mizota C, Shimoyama S, Yamanaka T (1999) An isotopic characterization of sulfur uptake by benthic animals from Tsuyazaki inlet, northern Kyushu. Jpn Benthos Res 54:81-85

Naraoka H, Naito T, Yamanaka T, Tsunogai U, Fujikura K (2008) A multi-isotope study of deep-sea mussels at three different hydrothermal vent sites in the northwestern Pacific. Chem Geol 255:25-32. doi:10.1016/j.chemgeo.2008.05.015

Nelson DC, Fisher CR (1995) In: Karl DM (ed) Chemoauto- trophic and Methanotrophic Endosymbiotic bacteria at deep-sea vents and seeps: the microbiology of deep-sea hydrothermal vent habitats. CRC, Boca Raton, pp 125-167

Nishijima M, Lindsay DJ, Hata J, Nakamura A, Kasai H, Ise Y, Fisher CR, Fujiwara Y, Kawato M, Maruyama T (2010) Association of Thioautotrophic bacteria with deep-sea sponges. Mar Biotechnol 12:253-260. doi:10.1007/s10126-009-9253-7

Ohara Y, Reagan MK, Fujikura K, Watanabe H, Michibayashi K, Ishii T, Stern RJ, Pujana I, Martinez F, Girard G, Ribeiro J, Brounce M, Komori N, Kino M (2012) A serpentinite-hosted ecosystem in the Southern Mariana Forearc. Proc Natl Acad Sci USA 109 (8):2831-2835. doi:10.1073/pnas.102005109

Okutani T, Soh W (2005) Calyptogena (Archivesicd) garuda, a magnificent new species of Vesicomyid Bivalve from the Java Trench, Indonesia. Venus J Malacol Soc Japan 64(1-2):23-29

Page HM, Fisher CR, Childress JJ (1990) Role of filter-feeding in the nutritional biology of a deep-sea mussel with methanotrophic symbionts. Mar Biol 104(2):251-257. doi:10.1007/BF01313266

Page HM, Fiala-Medioni A, Fisher CR, Childress JJ (1991) Experimental evidence for filter-feeding by the hydrothermal vent mussel, Bathymodiolus thermophilus. Deep Sea Res Part A Oceanogr Res Papers 38(12):1455-1461

Rees CE, Jenkins WJ, Monster J (1978) The sulphur isotopic composition of ocean water sulphate. Geochim Cosmochim Acta 42:377-381. doi:10.1016/0016-7037(78)90268-5

Saino T, Ohta $\mathrm{S}(1989){ }^{13} \mathrm{C} /{ }^{12} \mathrm{C}$ and ${ }^{15} \mathrm{~N} /{ }^{14} \mathrm{~N}$ ratios of vesicomyid lams and a vestimentiferan tube worm in the subduction zone east of Japan. Palaeogeogr Palaeoclimatol Palaeoecol 71:169-178. doi:10. 1016/0031-0182(89)90036-9

Sakai H, Gamo T, Endow K, Ishibashi J, Ishizuka T, Yanagisawa F, Kusakabe M, Akagi T, Igarashi G, Ohta S (1987) Geochemical study of the bathyal seep communities at the Hatsushima site, Sagami Bay, central Japan. Geochem J 21:227-236

Sakai H, Gamo T, Kim E-S, Shitashima K, Yanagisawa F, Tsutsumi M, Ishibashi J, Sano Y, Wakita H (1990) Unique chemistry of the hydrothermaql solution in the Mid-Okinawa Trough backark basin. Geophys Res Lett 17:2133-2136. doi:10.1029/GL017i012p02133

Schoell M (1988) Multiple origins of methane in the earth. Chem Geol 71:1-10

Silverman MP, Oyama VI (1968) Automatic apparatus for sampling and preparing gases for mass spectral studies of carbon isotope fractionation during methane metabolism. Anal Chem 40:1833-1837

Takano Y, Kobayashi K, Yamanaka T, Marumo K, Urabe T (2004) Amino acids in $308{ }^{\circ} \mathrm{C}$ deep-sea hydrothermal sub-vent at the Suiyo Seamount, Izu-Bonin Arc. Pacific Ocean Earth Planet Sci Lett 219:147-153. doi:10.1016/S0012-821X(03)00699-X

Thode HG (1988) Sulphur isotopes in nature and the environment: an overview. In: Krouse HR, Grinenko VA (eds) Stable isotopes: natural and anthropogenic sulphur in the environment. SCOPE43, Wiley, Chichester, pp 7-26

Tsugaru R, Tamaki Y, Sato M, Kimura M, Shimamura K (1991) Report on DELP 1988 cruises in the Okinawa Trough: part 4, preliminary report on the sediment samples. Bull Earthquake Res Inst 66:71-89 
Tsunogai U, Yoshida N, Ishibashi J, Gamo T (2000) Carbon isotopic distribution of methane in deep-sea hydrothermal plume, Myojin Knoll Caldera, Izu-Bonin arc: implications for microbial methane oxidation in the oceans and applications to heat flux estimation. Geochim Cosmochim Acta 64:2439-2452. doi:10.1016/S00167037(00)00374-4

Tsunogai U, Toki T, Nakayama N, Gamo T, Kato H, Kaneko S (2003) WHATS: a new multi-bottle gas-tight sampler for sea-floor vent fluids. Chikyukagaku (Geochemistry) 37(3):101-109 (in Japanese with English abstract)

Tsunogai U, Nakagawa F, Gamo T, Ishibashi J (2005) Stable isotopic compositions of methane and carbon monoxide in the Suiyo hydrothermal plume, Izu-Bonin arc: Tracers for microbial consumption/ production. Earth Planet Sci Lett 237:326-340

Tsunogai UA, Kosaka N, Nakayama DD, Komatsu U, Konno S, Kameyama F, Nakagawa H, Sumino K, Nagao KF, Machiyama H (2010) Origin and fate of deep-sea seeping methane bubbles at Kuroshima Knoll, Ryukyu forearc region, Japan. Geochem J 44 (6):461-476

Van Dover CL (2000) The ecology of deep-sea hydrothermal vents. Princeton University Press, New Jersey, p 424

Van Dover CL, Humphris SE, Fornari D, Cavanaugh CM, Collier R, Goffredi SK, Hashimoto J, Lilley MD, Reysenbach AL, Shank TM, Von Damm KL, Banta A, Gallant RM, Götz D, Green D, Hall J, Harmer TL, Hurtado LA, Johnson P, McKiness ZP, Meredith C, Olson E, Pan IL, Turnipseed M, Won Y, Young CR III, Vrijenhoek RC (2001) Biogeography and ecological setting of Indian Ocean hydrothermal vents. Science 294:818-823. doi:10.1126/science. 1064574

Von Damm KL, Edmond JM, Grant B, Measures CI, Walden B, Weiss RF (1985) Chemistry of submarine hydrothermal solutions at $21^{\circ} \mathrm{N}$, East Pacific Rise. Geochim Cosmochim Acta 49:2197-2220. doi:10.1016/0016-7037(85)90222-4

Wheat CG et al (2003) Hydrothermal venting in the southernmost portion of the Mariana backarc spreading center at $12^{\circ} 57^{\prime} \mathrm{N}$. Eos Trans AGU 84(46), Fall Meet. Suppl., Abstract V32A-0920
Yamanaka T, Murae T, Chiba H (1999) Isotopic fractionation of sulfur in micro zones of tidal flat sediments. Geochem J 33 (2):89-99

Yamanaka T, Shimoyama S, Mizota C (2000a) An evaluation of source sulfur in soft tissues of marine and freshwater benthic animals from Japan using stable isotope analysis. Benthos Res 55:17-22

Yamanaka T, Mizota C, Maki Y, Fujikura K, Chiba H (2000b) Sulfur isotope composition of soft tissues of deep-sea mussels, Bathymodiolus spp., in Japanese waters. Benthos Res 55:63-68

Yamanaka T, Mizota C, Fujiwara Y, Chiba H, Hashimoto J, Gamo T, Okudaira T (2003a) Sulfur-isotopic composition of the deep-sea mussel Bathymodiolus marisindicus from currently active hydrothermal vents in the Indian Ocean. J Mar Biol Assoc UK 83:841-848. doi:10.1017/S0025315403007872h

Yamanaka T, Mizota C, Satake H, Kouzuma F, Gamo T, Tsunogai U, Miwa T, Fujioka K (2003b) Stable isotope evidence for a putative endosymbiont-based lithotrophic Bathymodiolus sp. mussel community atop a serpentine seamount. Geomicrobiol J 20(3):185-197. doi:10.1080/01490450390206674

Yamanaka T, Maeto K, Akashi H, Ishibashi J, Miyoshi Y, Okamura K, Noguchi T, Kuwahara Y, Toki T, Tsunogai U, Ura T, Nakatani T, Maki T, Kubokawa K, Chiba H (2013) Shallow submarine hydrothermal activity with significant contribution of magmatic water producing talc chimneys in the Wakamiko Crater of Kagoshima Bay, southern Kyushu, Japan. J Volcanol Geotherm Res 258:74-84. doi:10.1016/j.jvolgeores.2013.04.007

Yanagisawa F, Sakai H (1983) Thermal decomposition of barium sulfate-vanadium pentaoxide-silica glass mixtures for preparation of sulfur dioxide in sulfur isotope ratio measurements. Anal Chem 55:985-987. doi:10.1021/ac00257a046

Yoneyama T, Kamachi K, Yamaya T, Mae T (1993) Fractionation of nitrogen isotopes by glutamine synthetase isolated from spinach leaves. Plant Cell Physiol 34:489-491 